University of Nebraska - Lincoln

DigitalCommons@University of Nebraska - Lincoln

\title{
Land use/land cover changes and climate: modeling analysis and observational evidence
}

\author{
Roger A. Pielke Sr. \\ University of Colorado at Boulder, pielkesr@cires.colorado.edu \\ Andy Pitman \\ University of New South Wales \\ Dev Niyogi \\ Purdue, climate@purdue.edu \\ Rezaul Mahmood \\ University of Nebraska - Lincoln \\ Clive McAlpine \\ University of Queensland, c.mcalpine@uq.edu.au
}

See next page for additional authors

Follow this and additional works at: https://digitalcommons.unl.edu/natrespapers

Part of the Natural Resources and Conservation Commons, Natural Resources Management and Policy Commons, and the Other Environmental Sciences Commons

Pielke, Roger A. Sr.; Pitman, Andy; Niyogi, Dev; Mahmood, Rezaul; McAlpine, Clive; Hossain, Faisal; Goldewijk, Kees Klein; Nair, Udaysankar S.; Betts, Richard; Fall, Souleymane; Reichstein, Markus; Kabat, Pavel; and de Noblet, Nathalie, "Land use/land cover changes and climate: modeling analysis and observational evidence" (2011). Papers in Natural Resources. 1260.

https://digitalcommons.unl.edu/natrespapers/1260

This Article is brought to you for free and open access by the Natural Resources, School of at DigitalCommons@University of Nebraska - Lincoln. It has been accepted for inclusion in Papers in Natural Resources by an authorized administrator of DigitalCommons@University of Nebraska - Lincoln. 


\section{Authors}

Roger A. Pielke Sr., Andy Pitman, Dev Niyogi, Rezaul Mahmood, Clive McAlpine, Faisal Hossain, Kees Klein Goldewijk, Udaysankar S. Nair, Richard Betts, Souleymane Fall, Markus Reichstein, Pavel Kabat, and Nathalie de Noblet 


\title{
Land use/land cover changes and climate: modeling analysis and observational evidence
}

\author{
Roger A. Pielke, Sr., ${ }^{1}$ Andy Pitman, ${ }^{2}$ Dev Niyogi, ${ }^{3,4}$ \\ Rezaul Mahmood, ${ }^{5}$ Clive McAlpine, ${ }^{6}$ Faisal Hossain, ${ }^{7}$ \\ Kees Klein Goldewijk, ${ }^{8}$ Udaysankar Nair, ${ }^{9}$ Richard Betts, ${ }^{10}$ \\ Souleymane Fall, ${ }^{11}$ Markus Reichstein, ${ }^{12}$ Pavel Kabat ${ }^{13}$ \\ and Nathalie de Noblet ${ }^{14}$
}

1 University of Colorado, CIRES, Boulder, CO, USA

2 ARC Centre of Excellence for Climate System Science, The University of New South Wales, Sydney, Australia

3 Department of Agronomy, Crops and Earth System Sciences, Purdue University, West Lafayette, IN, USA

4 Department of Earth and Atmospheric Sciences, Purdue University, West Lafayette, IN, USA

5 Department of Geography and Geology, Western Kentucky University, Bowling Green, KY, USA

6 The University of Queensland, School of Geography, Planning and Environmental Management, Brisbane, Australia

7 Department of Civil and Environmental Engineering, Tennessee Technological University, Cookeville, TN, USA

8 Climate, Air en Energy, PBL Netherlands Environmental Assessment Agency, Ant. van Leeuwenhoeklaan 9, MA, Bilthoven, P.O. Box 303, The Netherlands

9 Department of Atmospheric Science, University of Alabama in Huntsville, Huntsville, AL, USA

10 Met Office, Hadley Centre for Climate Prediction and Research, Bracknell, Berkshire, UK

11 College of Agricultural, Environmental and Natural Sciences and College of Engineering and Physical Sciences, 308 Kresge Center, Tuskegee University, Tuskegee, AL, USA

12 Biogeochemical Model-Data Integration Group, Max-Planck- Institute for Biogeochemistry, Jena, Hans-Knöll-Str. 10, Jena, Germany

13 P.0. Box 9101, Wageningen, The Netherlands

14 Laboratoire des Sciences du Climat et de l'Environnement Unité mixte, CEA-CNRS-UVSQ

Orme des Merisiers-Bat. 712 Point Courrier 13291191 Gif-sur-Yvette Cedex, France

Correspondence - R.A. Pielke, Sr., pielkesr@cires.colorado.edu

Published in WIREs Climate Change 2 (November/December 2011), pp 828-850.

doi: $10.1002 /$ wcc. 144

Copyright (C) 2011 John Wiley \& Sons, Ltd. Used by permission. 


\begin{abstract}
This article summarizes the changes in landscape structure because of human land management over the last several centuries, and using observed and modeled data, documents how these changes have altered biogeophysical and biogeochemical surface fluxes on the local, mesoscale, and regional scales. Remaining research issues are presented including whether these landscape changes alter large-scale atmospheric circulation patterns far from where the land use and land cover changes occur. We conclude that existing climate assessments have not yet adequately factored in this climate forcing. For those regions that have undergone intensive human landscape change, or would undergo intensive change in the future, we conclude that the failure to factor in this forcing risks a misalignment of investment in climate mitigation and adaptation.
\end{abstract}

\title{
Introduction
}

A great deal of attention is devoted to changes in atmospheric composition and the associated regional responses. Less attention is given to the direct influence by human activity on regional climate caused by modification of the atmosphere's lower boundary - the Earth's surface. Land use/land cover change (LULCC), as discussed in this article, concerns human-caused changes that affect the biophysics, biogeochemistry, and biogeography of the terrestrial surface and its affect on the atmosphere. ${ }^{1-3}$ Vast areas of the Earth's terrestrial surface have undergone LULCC. ${ }^{4,5}$ LULCC effects on climate include direct alterations in surface solar and longwave radiation and in atmospheric turbulence which result in changes in the fluxes of momentum, heat, water vapor, and carbon dioxide as well as other trace gases and both inorganic and biogenic aerosols including dust between vegetation, soils, and the atmosphere. ${ }^{1,6-17}$

In terms of an effect on the global average radiative imbalance, Forster et al..$^{18}$ suggest that this direct biogeophysical radiative impact of LULCC since preindustrial times is a reduction in the global average radiative forcing of $0.2 \pm 0.2 \mathrm{~W} \mathrm{~m}^{-2}$ which is small relative to other global climate forcings. Reasoning of this kind has led to the role of LULCC being mostly omitted from the climate models used in previous Intergovernmental Panel on Climate Change (IPCC) assessments of climate projections and historical reconstructions (although deforestation is included via emission scenarios of $\mathrm{CO}_{2}$ ).

The role of climate science, however, extends beyond forming future emission mitigation policies. The role of LULCC is not limited to radiative 
forcing of climate and is not adequately assessed as a globally averaged forcing. LULCC is a highly regionalized phenomenon ${ }^{18,19}$ with regionalscale climate impacts that can vary in the sign of the change. In terms of an average flux, in regions of significant LULCC, a major perturbation occurs to the net radiation, to the partitioning of this net radiation between the two turbulent energy fluxes (sensible and latent heat), as well as changes in the aerodynamic roughness of the land surface. ${ }^{20,21}$ LULCC also fundamentally changes the biogeochemistry, including the terrestrial carbon exchange, and fluxes of trace gases (such as nitrous oxide), biological volatile organic compounds, and aerosols (including dust). Urban landscapes add additional direct heating of the lower atmosphere. The biogeography is also changed as flora and fauna are altered by deliberate and inadvertent land management and the introduction of invasive species. $^{22}$

The primary objective of this paper is to review ${ }^{23}$ the biogeophysical impacts of LULCC on climate, identify key unanswered questions, and offer recommendations for LULCC-related climate and Earth system research. We rely primarily on observational studies but have also included relevant modeling research where observations are limited.

\section{Historical Global Land Use/Land Cover Changes [Focusing on 1750 to the Present]}

The distribution of historical LULCC over time is highly regionalized (Figures 1-3). By 1500, large areas of Western Europe had been partially cleared for agriculture and for timber harvesting (Figure 1(a)). LULCC intensified, particularly in Western Europe, through 1800 while significant LULCC also occurred over much of Asia including India and China. Indeed, by 1750, 7.9-9.2 million $\mathrm{km}^{2}$ (6-7\%) of the global land surface were in cultivation ${ }^{18,24,25}$ although only Western Europe and perhaps parts of Northern China had the intensity of LULCC with more than $\sim 60 \%$ agricultural cover for a given region (Figure 1(b)-(d)). By 1990, $45.7-51.3 \mathrm{~km}^{2}$ of the global land surface ${ }^{24,25}(35-39 \%)$ was being cultivated with forest cover decreased by approximately 11 million $\mathrm{km}^{2}$. Intensive LULCC had impacted parts of the United States, much of Western Europe, India, Northern China, and elsewhere. Large areas of the Southern Hemisphere underwent LULCC throughout the 19th century. 


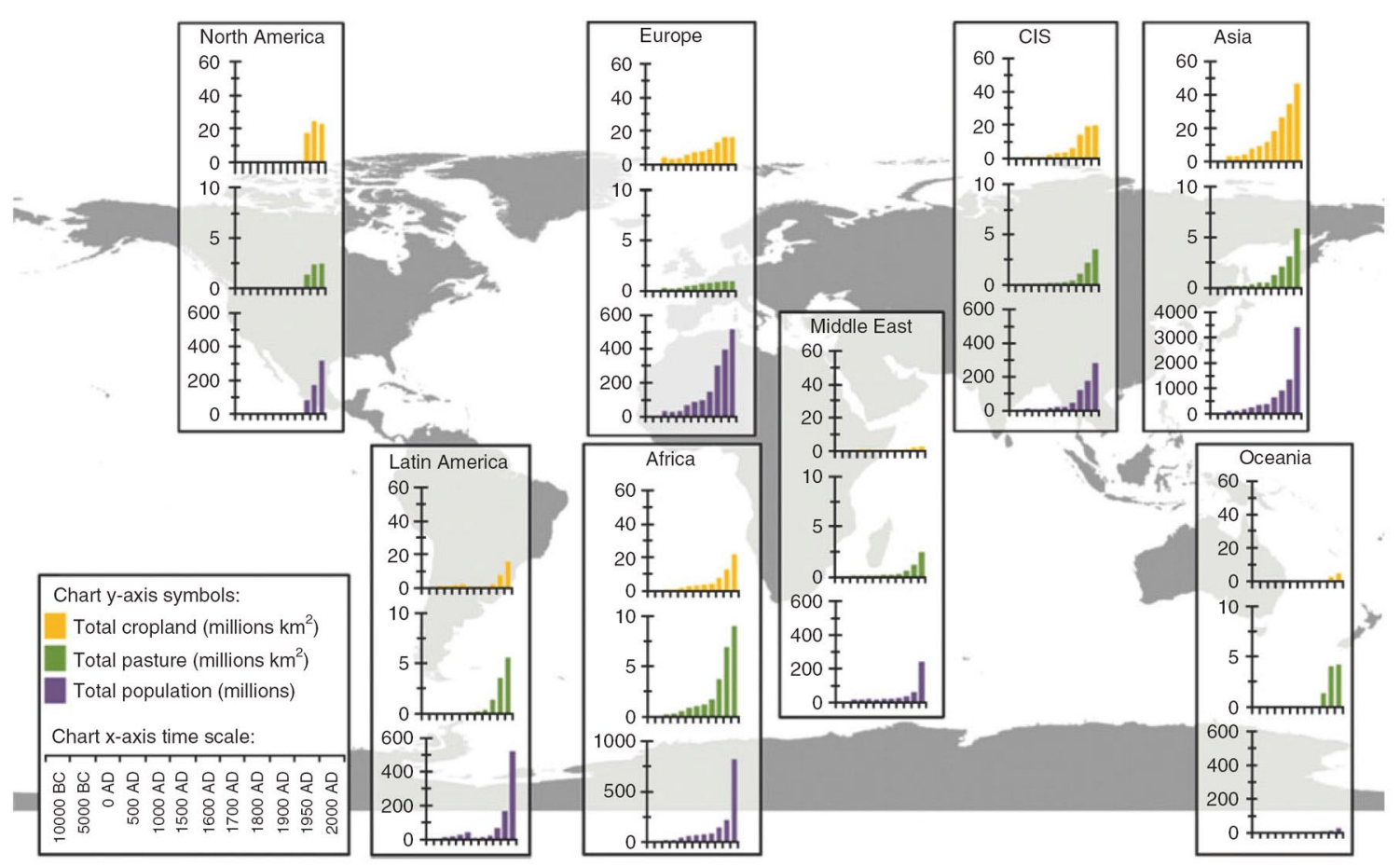

Figure 1 Long-term historical global estimates for population, cropland, and pasture. (Reprinted with permission from Refs 29. Copyright 2010 SAGE Publications, Inc.)

By 2000 (Figure 1(f)), only a few desert regions, the central Amazon and Congo Basins, and the Arctic and Antarctic (not shown) had not been affected by LULCC (see Refs 24-28; Klein Goldewijk et al..$^{29,30}$ provides details of the methods used to reconstruct historical LULCC).

Agricultural expansion and intensification were the major drivers of global LULCC. Klein Goldewijk et al. ${ }^{30}$ estimates the global area of cropland increased from 300 million ha in 1700 to 1530 million ha in 2000. This is a lower estimate than Ramankutty and Foley ${ }^{24}$ who estimated 400 million ha in 1700 and 2000 million ha in 1990, but similar to the 1400 million ha estimate of Williams ${ }^{4}$ and the 1500 million ha estimate of Richards, ${ }^{31}$ although both were for the year 1980. The estimate of Matthews ${ }^{32}$ of 1760 million ha of cropland in 1980 is somewhat higher. Estimates of agricultural land currently under irrigation ranges from 250 million ha ${ }^{33}$ to 274 million ha. ${ }^{34}$

Irrespective of which estimates are used, the global area of cropland has increased dramatically and is now almost $11 \%$ of the total land area. ${ }^{4,25,31-33}$ The global area used for grazing livestock has increased at 

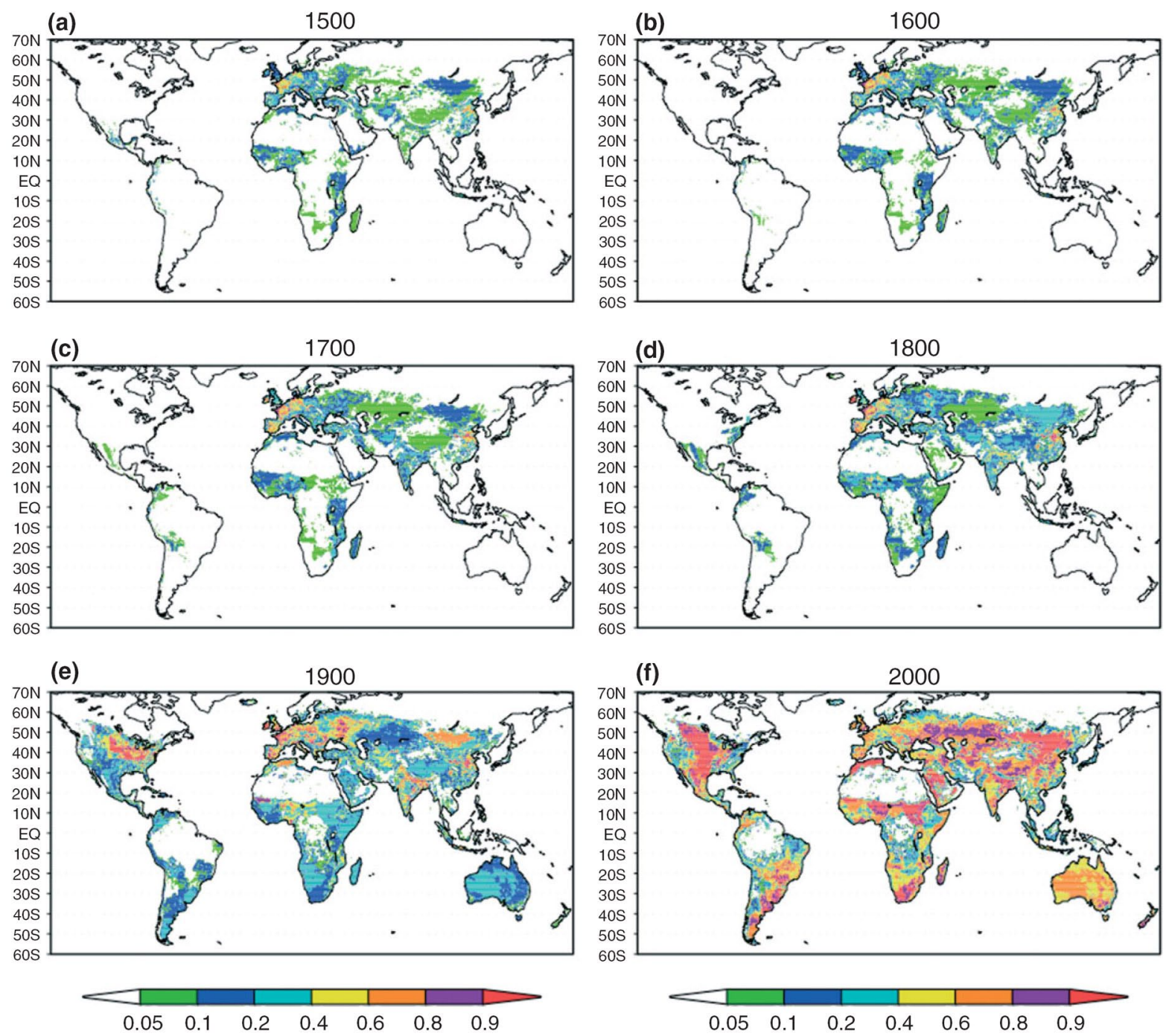

Figure 2 Reconstructed and projected LULCC for various time periods. The scale is the relative fraction of any grid box containing the sum of pasture or crops. These data were obtained from the LULCC data downloaded from the Land Use Harmonization website at http://luh.unh.edu . Note: CIS stands for Commonwealth of Independent States, a regional organization whose participating countries are former Soviet Republics, formed during the breakup of the Soviet Union. The analysis of the type of landscape continues to undergo refinement (e.g., much of Australia is shown as pasture when a large fraction is ungrazed semiarid and arid).

a stunning rate, from 324 million ha in 1700 to 3429 million ha in 2000, representing $25 \%$ of the total land area. ${ }^{31}$ Urban landscapes formed less than $1 \%$ of the total land area up until the mid-20th century and still occupies less than $5 \%$ of the total global land area. ${ }^{30,35}$ Irrigated areas 


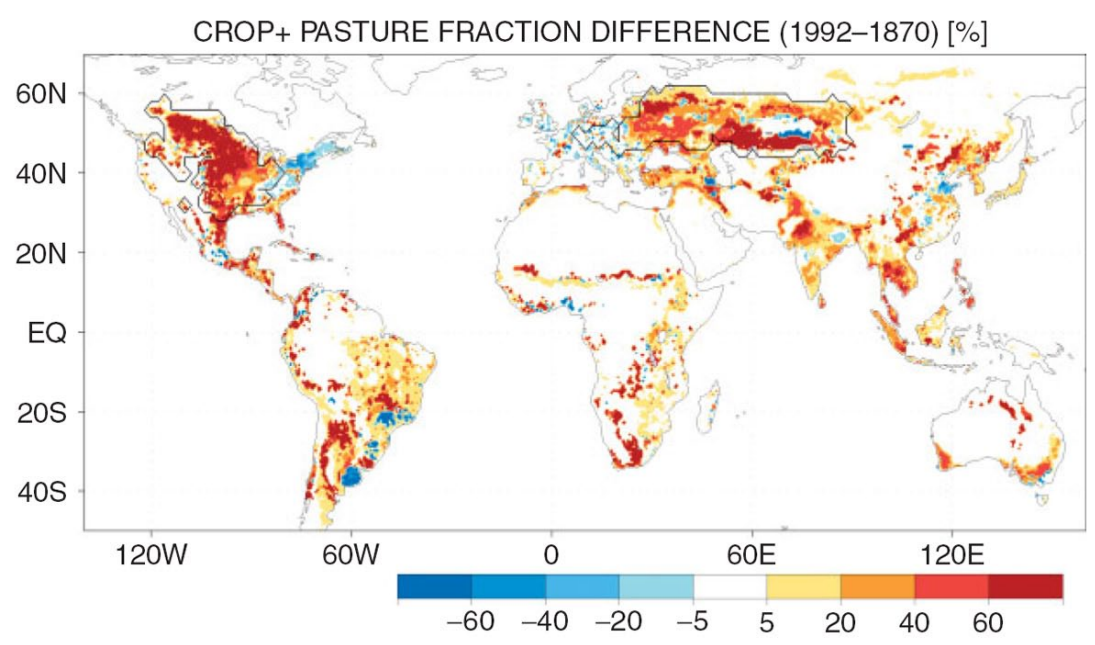

Figure 3 Changes in the extent covered with crops and pasture between present-day (1992) and preindustrial times (1870). Yellow and red colors are used when the extent of anthropogenic areas have increased since preindustrial times, while blue colors refer to abandoned lands. The two boxes that are drawn on the map highlight the regions that will further be used to draw Figure 11 (hereafter referred to as North America and Eurasia).

are also relatively small in terms of global LULCC. It is important to note that urban, irrigated, and croplands are not uniformly distributed globally but rather are highly regionalized into concentrated landscape perturbations as discussed below.

\section{North America}

In the United States, the Homestead Act of 1862 (providing each settler 160 acres of free government land for cultivation over at least 5 years) led to rapid settlement of public lands in the next decades. The end of the Civil War and the disbanding of armies further stimulated this process, and the Great Plains region attracted people displaced by the war. The increasing flow of European migrants added further to the settlement of the Midwest and the building of canals in the early 1800s, and the subsequent expansion of railroads facilitated the rapid transport of goods to markets. ${ }^{36}$ The rapid increase of farmland also led to a huge consumption of wood; for example, farm fencing in Kentucky alone during the 1870 s was estimated to consume 10 million trees annually. ${ }^{37}$ Steyaert 
and $\operatorname{Knox}^{38}$ document the vast conversion of almost all of the land in the eastern 2/3 of the United States from its natural state by 1920. Canada experienced similar trends where the agricultural area increased almost sixfold from 12 million ha in 1871 to nearly 70 million ha at the end of the 20th century (derived from Ref. 39).

\section{Latin America}

The 19th and the early 20th century were the high point of large agricultural plantations in Latin America. Earlier successes in the Caribbean with sugar and cotton in North America created confidence and finances to look further into the New World. European exploitation of forests in Brazil started with the rubber plantations along the Atlantic coast, and this was soon followed by sugar cane. The Araucaria forests in southern Brazil were reduced from 25 million ha to their present extent of 445,000 ha, ${ }^{37}$ with the bulk of the timber simply burned to make way for agriculture. The introduction of cash crops added extra pressure on the remaining forest area in Brazil. Three million hectares of forest was converted into coffee plantations during the 19 th century. ${ }^{36}$

In the last decades of the 20th century, widespread conversion of native forests to cattle ranching occurred in Brazil, Argentina, Colombia, and other Latin American countries. Large-scale infrastructure projects like the Trans-Amazonian Highway opened up pristine tropical forest areas, often followed by the spread of settlers and ranchers. Between 1850 and 1985, 370 million ha of forest in Latin America was converted to other land uses. ${ }^{36}$ Most of this reduction of forest area was due to the expansion of pasture (for cattle ranching, 44\% of the reduction), croplands (25\%), degraded lands (20\%), and shifting cultivation (10\%). Grigg ${ }^{40}$ presented figures for the expansion of cropland in Argentina, 6 million ha in 1900, 24 million ha in 1930, and 22 million ha in 1960. In Colombia, the estimated transformed area rose from approximately 15 million ha in 1500 to 42 million ha in 2000, and land use changed from predominantly cropping in 1500 to predominantly grazing in $2000 .{ }^{41}$ In recent years, the rate of deforestation has slowed in the Brazilian Amazon. However, land conversion pressures continue in the Colombian Amazon, the Cerrado of Brazil, and in dry Chaco forests of Paraguay, northern Argentina, and Bolivia. 


\section{Africa}

There is not as much information on deforestation in the African continent in comparison to other continents. Some estimates of historical forest areas are listed by Mather ${ }^{37}$ for the Ivory Coast (14.5 million ha in 1900 and 3.9 million ha in 1980), Liberia (6.5 million ha in 1920 and 2 million ha in 1980), and Ghana (9.8 million ha in 1920 and 1.7 million ha in 1980). Intensive forest clearing is currently occurring in Gabon and in the Congo Basin. Clearance for plantations (cacao, coffee) occurred at a level that is generally not as high as in Southeast Asia. The expansion of cropland (driven by population growth), illegal and destructive logging operations, overgrazing, and droughts caused a decrease of the total forest/woodland area of 735 million ha in 1961 to 681 million ha in 2005 , a loss of 54 million ha in four and one-half decades. ${ }^{42}$

\section{Europe (Including the Former USSR)}

Already during the 16th and 17th centuries, intensive trade existed between central and western European ports. The European river trading towns were major import centers for shipped goods from the Baltic region. Poland, Hungary, and Russia were important providers of timber and grain. Estimates for the expansion of cropland in Russia range widely from 49 to 95 million ha in 1860, 113 to 208 million ha in 1900, 109 to 259 million ha in 1930, and 196 to 369 million ha in $1960 .{ }^{36}$ Most countries in this region have expanded and intensified their land use activities over the last 300 years. However, land cover change has stabilized or even reversed during the past 50 years with the 'Arable and Permanent Crops' area decreasing from 391 million ha in 1961 to 295 million ha in $2005 .{ }^{42}$

\section{Asia}

China has cultivated wheat and rice for thousands of years, especially in the northeastern provinces. Late 17 th century China finally opened its borders to the emerging world economy which led to further expansion of cultivated land. Richards ${ }^{31}$ suggests cultivated area in China grew from $33( \pm 7)$ million ha in 1600 to $63( \pm 7)$ million ha in 1776, reaching $81( \pm 3)$ million ha in 1873. In the 18th century, intensification and 
commercial cropping replaced shifting cultivation in the hills. Land clearance on slopes resulted in erosion, frequent landslides, and flash floods. During the latest decades, efforts have been undertaken to restore the degraded Loess plateau and up to $35,000 \mathrm{~km}^{2}$ have been successfully restored to prime agricultural land (Liu, personal communication). Recently, the forest area in China has increased due to large-scale reforestation programs. ${ }^{43}$

Richards and Flint ${ }^{43}$ assessed land use changes in 13 countries in tropical Asia for 1880-1980. Since 1900 in this region, forests, woodlands, and wetlands declined by almost 50\% (131 million ha) while the cultivated area increased by 106 million ha (almost doubled). Thus, 81\% of the lost forest and wetland vegetation has been converted into agricultural land. In recent decades, rapid deforestation has occurred in Southeast Asia due to logging pressures and the expansion of palm oil plantations.

\section{Australia}

Two centuries of European settlement has transformed the Australian continent. ${ }^{44}$ Nationally, estimates of landscape conversion range from 0.4 to 9.7 million ha in 1860, 3 to 16 million ha in 1900, 10 to 22 million ha in 1930, and 12 to 35 million ha in $1960 .{ }^{24,30,45,46}$ Within the intensive land use zone of southeast and southwest Australia, approximately 50\% of native forests and $65 \%$ of native woodlands have been cleared or severely modified. Since World War II, over 13 million ha of native vegetation were cleared in southwest Australia, mainly for cultivation of winter crops. ${ }^{44}$ Recent satellite monitoring indicates that LULCC is still highly active, with Queensland the most affected region. ${ }^{47}$ The clearance of native vegetation in Queensland peaked at over 500,000 ha/year-1 between 2000 and $2004,{ }^{47}$ mainly for beef cattle pastures. This ranked the region 5 th worldwide on deforestation rate. ${ }^{48}$ Vast areas of semiarid and arid inland Australia are used for low intensity grazing and have not been transformed.

\section{Summary}

LULCC has clearly been extensive; only Antarctica, and boreal/tundra areas in Siberia, Canada, and parts of the Amazon and Congo have 
avoided large-scale conversion. In terms of climate the question is whether these LULCCs have altered local, regional, and global climate. The next section seeks to address this question using observed data and modeling simulations. Observed data is available for local in situ information, while satellite data is used to analyze impacts on mesoscale, regional, and global scales. One of the challenges for our assessment is that LULCC usually occurs on decadal and longer time scales such that the climatic signal requires observations over this time period. Periodic perturbations, such as ENSO for example, are easier to detect than those due LULCC.

Thus, the approach we have taken is to document local effects of LULCC and then to review selected modeling studies which were done to scale up to mesoscale, regional, and global scales. Models which are used to analyze effects of LULCC on climate are first compared with current climate conditions where data are available, and then LULCC sensitivity experiments are performed (such as comparing with model runs with natural landscapes).

\section{Changes in Surface Fluxes, Surface and Near-Surface Variables, and Boundary Layer Dynamics Because of Land Use/Land Cover Changes}

In this section, we focus on biogeophysical influences, but it is important to recognize that concurrent biogeochemical effects also occur. For example, regrowing forests tend to be large carbon sinks, but even oldgrowth forests can sequester carbon. ${ }^{49,50}$ Transpiration is closely connected to many ecological and biogeochemical processes ranging from nitrogen cycling ${ }^{51}$ to carbon uptake through photosynthesis. ${ }^{52}$ Recent studies that combine both biogeophysical and biogeochemical effects of LULCC include, for example, Houghton et al., ${ }^{53}$ Fearnside, ${ }^{54}$ Post and Kwon, ${ }^{55}$ and Schulze et al. ${ }^{56}$

Examples of the effect of LULCC on surface fluxes, surface and nearsurface variables and boundary layer dynamics for several geographic regions are given below. 


\section{South America}

In Amazonia, replacement of forest by pastures leads to an increase of albedo from approximately 0.13 to approximately 0.18 and a decrease in net radiation of approximately $11 \%$ at the surface. ${ }^{57}$ During the dry season, shallower rooted pasture vegetation experience a soil moisture deficit compared to deep rooted forest vegetation that has access to soil water in deeper layers. ${ }^{57}$ Thus the pasture regions experience a reduction in transpiration and latent heat flux and consequently an increased sensible heat flux. Higher sensible heat fluxes causes enhanced boundary layer development over pastures compared to forested regions with the planetary boundary layer (PBL) height being higher by up to $600 \mathrm{~m}$ over the pasture region. ${ }^{58,59}$

Souza et al. ${ }^{60}$ analyzed radiosonde observations over adjacent pasture and forest sites in Amazon over a period of 10 days during the dry season. During the time of peak sensible heat fluxes, average wind perturbations components below $3 \mathrm{~km}$ are directed from the forest to the pasture regions, while above $3 \mathrm{~km}$ it is directed from the pasture to the forest region. In the Brazilian Cerrado, satellite observations suggest that replacing natural vegetation with pasture has warmed the local climate by approximately $1.5^{\circ} \mathrm{C}$ through a decrease in transpiration which outweighs the increase in surface albedo. ${ }^{61}$

Loarie et al. ${ }^{61}$ found that natural flooding regimes, but also possibly human manipulation through dams and other agriculture manipulations, alter regional albedo. They found that large albedo increases $(>+2.8 \%)$ were 2.2 times more prevalent than similar decreases throughout South America. Changes in surface water drove most large albedo changes that were not caused by vegetative cover change. Beltran et al. ${ }^{62}$ report a potential strong influence of LULCC on the maximum temperatures in central Argentina in summer. Examples of other papers that demonstrate the role of LULCC in this continent document the role of deforestation in altering the onset of the rainy season in the Amazon ${ }^{63}$ and on cloud climatology. ${ }^{59}$ 


\section{Europe}

In a European synthesis based on boundary layer data, Teuling et al. ${ }^{64}$ showed that under well-watered conditions, grassland vegetation latent energy is larger than adjacent forests, while the forest exhibits much larger sensible heat fluxes, particularly under heat wave conditions. The reason for the high sensible heat fluxes from forests under these conditions include lower albedo, lower atmospheric resistance (higher roughness), and stronger stomatal control of the transpiration (i.e., the latent heat flux) compared to grassland (see also Refs 65, 66). With progressive drought, however, forests can maintain their moderate transpiration rates, while grasslands wilt and consequently exhibit higher sensible heat fluxes. ${ }^{61}$

\section{Australia}

Land cover change in southwest Australia has been linked to observed changes in surface energy fluxes, boundary layer evolution, and associated cloud formation. ${ }^{67-70}$ The area cleared for agriculture is readily visible in satellite imagery (Figure 4), because of higher albedo values over the agricultural region. A $750 \mathrm{~km}$ rabbit proof fence demarcates the boundary between the agricultural region and remnant native vegetation to the east. The agricultural region exhibits substantial seasonal change in albedo, increasing from 0.18 during the growing season in August to 0.27 after the wheat harvest in December, ${ }^{71}$ while values over the native vegetation region range from 0.08 in August and 0.12 in December. Aerodynamic roughness length is also higher over the native vegetation.

During the Bunny Fence Experiment in 2005, 2006, and 2007, aircraft observations ${ }^{70}$ show that the latent heat fluxes are low and exhibit relatively small variations over native vegetation during August and December (20-40 $\mathrm{W} \mathrm{m}^{-2}$ at $1200 \mathrm{LST}$ ). The latent heat fluxes over the agricultural region are very small after harvest (approximately $15 \mathrm{~W} \mathrm{~m}^{-2}$ at 1200 LST) in December, whereas the values during the growing season in August are substantially higher (approximately $50 \mathrm{~W} \mathrm{~m}^{-2}$ at $1200 \mathrm{LST}$ ). Sensible heat fluxes are consistently higher over the native vegetation region compared to agricultural areas during August to December resulting in vigorous boundary layer development and higher PBL heights. 


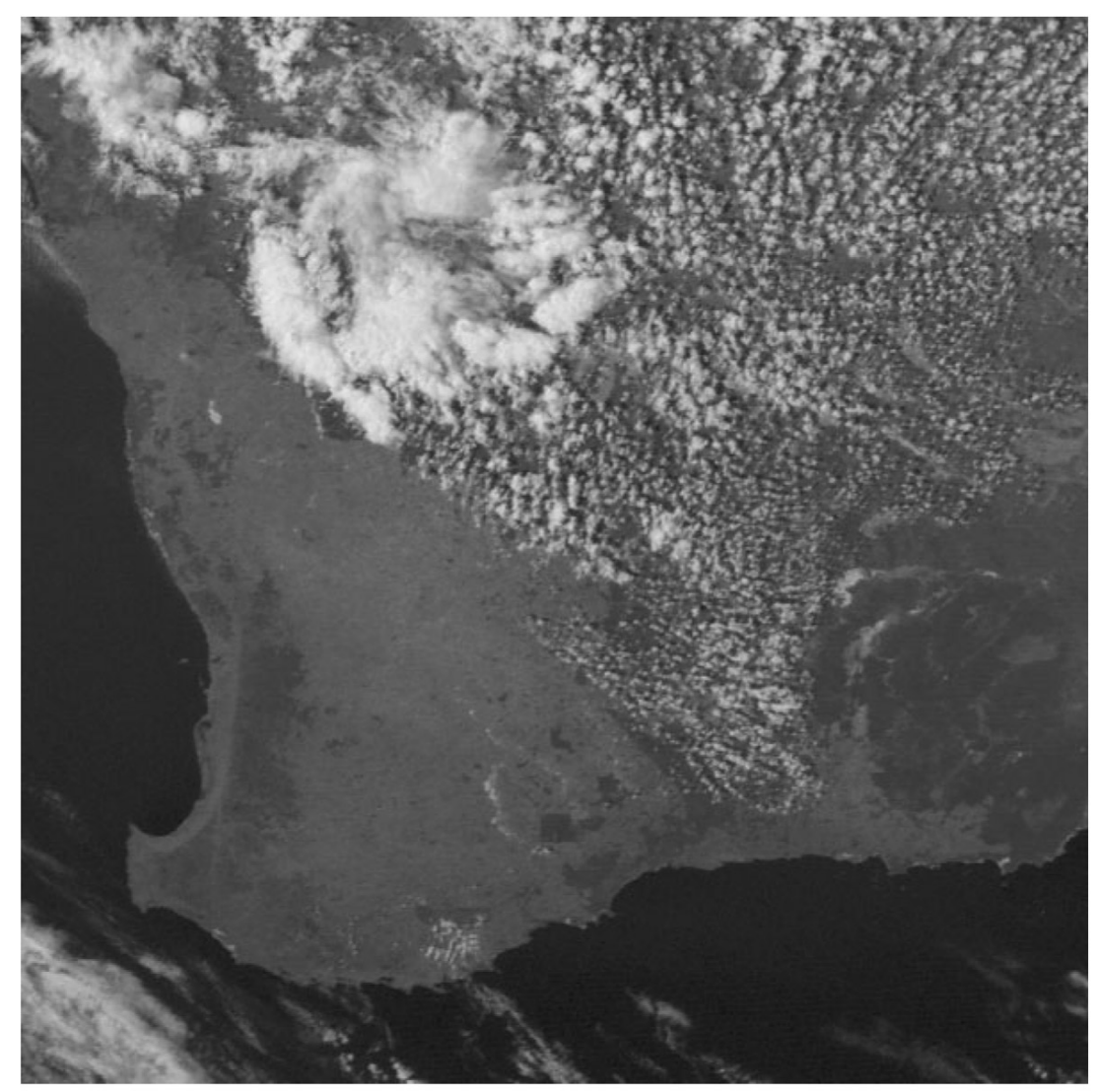

Figure 4 Geostationary Meteorological Satellite (GMS) visible channel imagery for January 3, 1999, 1500 LST over southwest Australia. The agricultural regions are clear, while boundary cloud formation occur over native vegetation areas. Note that the western extent of the cloud fields coincide approximately with the rabbit proof fence that demarcates the cleared areas from the regions of remnant native vegetation.

\section{Asia}

In India, widespread irrigation was adopted during the 1960s as part of the 'Green Revolution' (GR) to significantly increase crop production. ${ }^{72,73}$ Roy et al. ${ }^{74}$ examined the impacts of irrigation schemes on dry season temperature in northern India. Long-term temperature data were divided between pre-GR (1947-1964) and post-GR (1980-2003) periods. This study found a $0.34{ }^{\circ} \mathrm{C}$ cooling of growing season maximum temperatures during post-GR period. For individual growing season months, up to $0.53{ }^{\circ} \mathrm{C}$ cooling of maximum temperature was reported for the postGR period. Long-term temperature trends were largely negative and statistically significant. 
In a subsequent study, Roy et al. ${ }^{75}$ investigated impacts of irrigation on dry season non-monsoonal precipitation during pre- and post-GR period for northern India. The results suggest an increasing trend in precipitation during the post-GR period. For example, in eastern Madhya Pradesh, post-GR precipitation increases for the dry season was $2.40 \mathrm{~mm}_{\text {year }}{ }^{-1}$. Up to a $69 \mathrm{~mm}(121 \%)$ increase in the total amount of precipitation for growing seasons during the post-GR period was reported for some regions. Overall, irrigated regions showed a notable increase in precipitation during post-GR growing seasons with differences in growing season average precipitation between the pre- and post-GR periods statistically significant for most of the regions. However, the irrigation effect on climate could be season specific. For example, an opposite feedback was noted for northwest India (a subregion within northern India) for monsoon (wet) season irrigation and was shown to have contributed to reduced monsoon rainfall. ${ }^{76}$

Large-scale ground water irrigation observed using satellites ${ }^{73}$ has resulted in a series of regionally coherent feedbacks in India. This includes lower observed dry season surface temperature, ${ }^{74}$ higher observed convective available potential energy, ${ }^{76,77}$ an increase in dry season non-monsoonal rainfall, ${ }^{73}$ and a reduction in monsoonal rainfall ${ }^{75}$ over the irrigation region of northwest India. The latter effect is potentially a result of a feedback of the irrigation and early greening of the agricultural landscape which causes a reduction in the monsoon heat low and affects the $200 \mathrm{mb}$ wind circulation during active monsoons. ${ }^{76}$

Urbanization in Asia is also affecting the local and regional climate. Chen et al. ${ }^{78}$ found enhanced thunderstorm activity in Taipei, Taiwan compared to rural sites, with a $67 \%$ increase in afternoon/evening thunderstorms and $77 \%$ increase in rainfall associated with these thunderstorms. Zhou et al. ${ }^{79}$ showed urbanization impacts can be detected in the temperature datasets for China with a mean surface temperature increase of $0.05{ }^{\circ} \mathrm{C}$ decade ${ }^{-1}$ which they attributed to urbanization. An observational analysis of rainfall and urbanization dataset $\left(\mathrm{see}^{80}\right)$ points to a strong urbanization signature on the heavy rainfall climatology over the Indian monsoon region as discussed previously. 


\section{USA and Canada}

Steyaert and $\mathrm{Knox}^{, 38}$ using land records, were able to infer significant changes in albedo and surface aerodynamic roughness over the eastern $2 / 3$ of the United States since 1650 (Figures 5 and 6). Strack et al. ${ }^{81}$ suggest that the changes in surface roughness and stomatal resistance have caused present-day maximum and minimum temperatures in the eastern United States to warm by about 0.3 and $0.4{ }^{\circ} \mathrm{C}$, respectively, when compared to values in 1650 . In contrast, the maximum temperatures have remained about the same, while the minimums have cooled by about $0.1^{\circ} \mathrm{C}$ when compared to 1920 . Little change in precipitation was found. In another study based on observed data, Raymond et al. ${ }^{82}$ found

Albedo: 1650, 1850, 1920, 1992

(a)

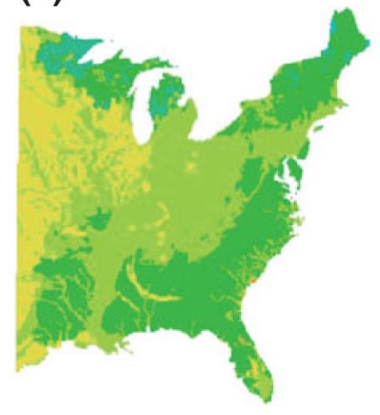

(c)

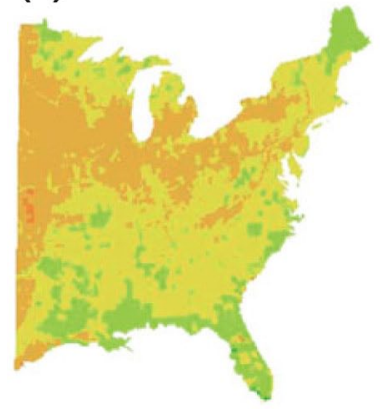

(b)

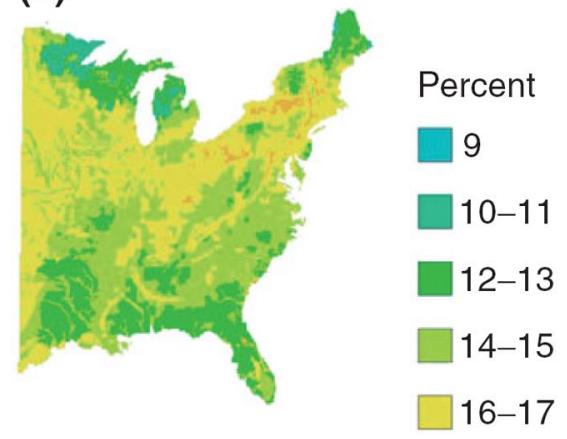

(d)

18-19

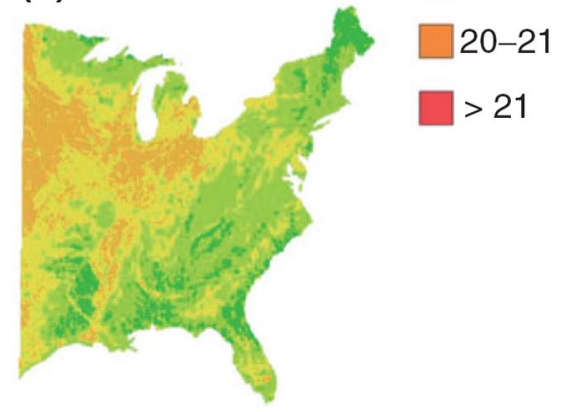

Figure 5 Changing patterns of $10 \mathrm{~km}$ averages of broadband solar albedo, contrasting (a) 1650, (b) 1850, (c) 1920, and (d) 1992. By 1920, most areas formerly covered by deciduous forests and dense native grasslands exhibited the higher peak-season shortwave albedo characteristic of agricultural crops and pastures. Increased average albedo also characterized postharvest landscapes that resulted from removal of oldgrowth conifer and mixed forests in the late 19th and early 20th centuries. (Reprinted with permission from Ref 38. Copyright 2008 American Geophysical Union) 
Surface roughness: 1650, 1850, 1920, 1992

(a)

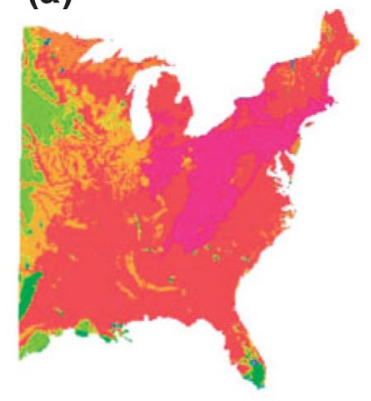

(c)

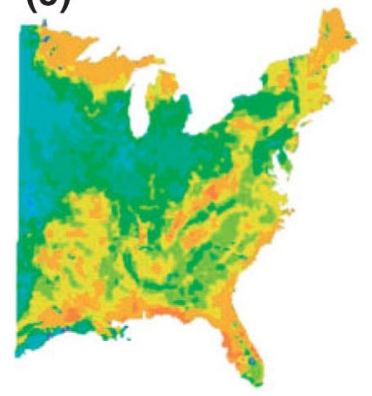

(b)

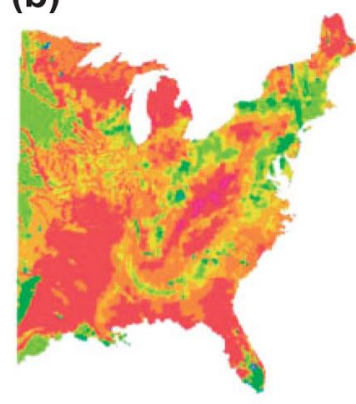

(d)

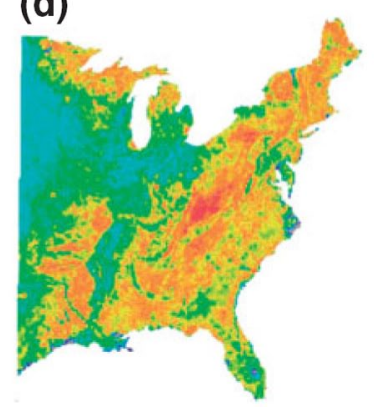

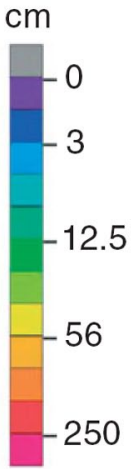

250

Figure 6 Patterns of aerodynamic surface roughness length (cm), as $10 \mathrm{~km}$ characteristic values displayed using a logarithmic color scale. Maps for (a) 1650, (b) 1850, (c) 1920, and (d) 1992 time slices. Characteristic roughness lengths track changes and patterns of land use, including settlement patterns in 1850 and the fragmented distribution of recovering forests of 1992. (Reprinted with permission from Ref 38. Copyright 2008 American Geophysical Union)

urban heat island (UHI) like impacts on mesoscale temperature due to the replacement of wetland forests with agriculture over the lower Mississippi river floodplains. Of particular interest is an increase of minimum temperature and lowering of daily temperature range in this region. In addition, a series of studies in the midwestern USA and southern Great Plains also reported links between surface vegetation conditions and convective cloud development. ${ }^{83-88}$ At a state level, in Oklahoma, Sun et al. ${ }^{89}$ found that for a stable atmospheric boundary layer over a heterogeneous landscape consisting of short and tall grasses, the average nighttime radiative flux difference between 48 and $2 \mathrm{~m}$ differs by up to $20 \mathrm{~W} \mathrm{~m}^{-2}$ depending on the location including an effect from landscape type. Significant differences in $2 \mathrm{~m}$ temperatures were found depending 
on the landscape and terrain. This effect of LULCC affecting nighttime temperatures is important as it affects multi-decadal minimum temperature trends which are then used in computing the mean temperature. ${ }^{10}$ McPherson et al. ${ }^{90}$ reported a cool anomaly of maximum temperatures over a rainfed wheat growing area of western Oklahoma, USA, as well as higher dewpoint temperatures over wheat growing areas compared to surrounding native grasslands in Oklahoma. These anomalies are linked to larger transpiration (and thus less sensible heating) due to the presence of the wheat.

Mahmood et al. ${ }^{91-93}$ investigated the impact of irrigation on growing season (May through September) temperatures in the Ogallala aquifer region. These studies found cooling of up to $1.4{ }^{\circ} \mathrm{C}$ in the growing season mean maximum temperatures since 1945 at irrigated locations. Moreover, a decrease in long-term extreme maximum temperatures was found for irrigated locations. Mahmood et al. ${ }^{91}$ assessed the impacts of irrigation on near surface atmospheric moisture content using long-term dewpoint temperature data in Nebraska, USA. They found a $1.6^{\circ} \mathrm{C}$ increase in average growing season dewpoint temperature over irrigated areas, with up to $2.2^{\circ} \mathrm{C}$ increase for peak growing season months. Sandstrom et al. ${ }^{94}$ reported an increase in frequency of occurrence of extreme dewpoint temperature $\left(\geq 22^{\circ} \mathrm{C}\right)$ days in the central United States and suggested that LULCC is the primary cause of this increase.

For the Great Plains region, modeling studies by Adegoke et al. ${ }^{95}$ reported that the near ground domain-average temperature was 3.3 ${ }^{\circ} \mathrm{C}$ cooler and the surface latent heat flux was $42 \%$ higher due to irrigation. DeAngelis et al. ${ }^{96}$ reported an increase of $10-30 \%$ of rainfall downwind of the Ogallala aquifer that has been used for ground water-based irrigation in the Great Plains. Using reanalysis and in situ datasets, Fall et al. ${ }^{97}$ found that the shift to agriculture always results in a cooling and presents the largest magnitudes of cooling among all land conversion types. The conversion of barren areas and grasslands/ shrublands is associated with the largest cooling (around $-0.1^{\circ} \mathrm{C}$ ). A moderate or relatively small cooling occurs in previously forested and barren areas (around $-0.05^{\circ} \mathrm{C}$ ). Fall et al. ${ }^{98}$ concluded that there is a significant relationship between the amount of transpiring vegetation, temperature, and humidity changes for the USA (Figure 7). Christy et al. ${ }^{99}$ found that over the irrigated San Joaquin Valley, minimum temperatures increased significantly in all seasons, especially during the 


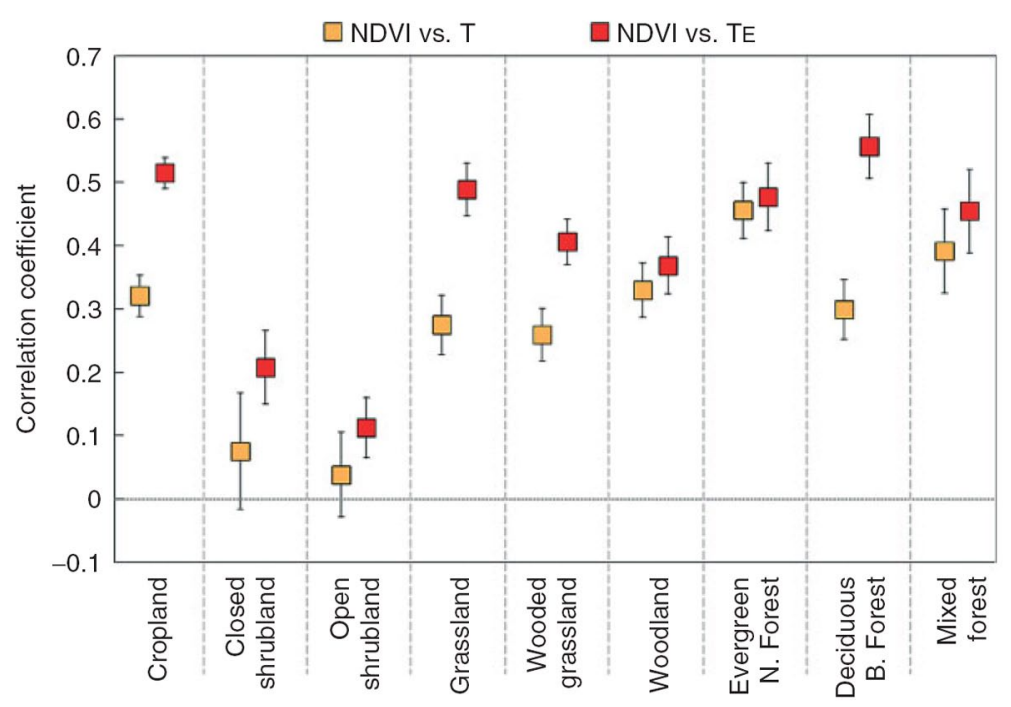

Figure 7 Mean correlation coefficient of Normalized Difference Vegetation Index (NDVI) versus near-surface Temperature (T) and Equivalent Temperature (TE) as a function of vegetation type. Mean correlation values and confidence interval were obtained using the ArcGIS Zonal Statistics method, which computes from a gridded dataset summary statistics for each zone (here, vegetation types). Error bars denote 95\% confidence intervals at 5\%. (Reprinted with permission from Ref 98. Copyright 2010 Wiley Blackwell)

summer and fall (exceeding $+0.25^{\circ} \mathrm{C}$ decade ${ }^{-1}$ ), because of the change of high-albedo soils into a darker, moister, vegetated surface. In addition, Bonfils and Lobell ${ }^{100}$ and Lobell and Bonfils ${ }^{101}$ reported lowering of growing season mean temperature and mean maximum temperature in the irrigated area of California, USA.

While irrigation has been reported to enhance rainfall, the converse impact has been observed for the draining of wetlands in Florida for citrus production. ${ }^{102} \mathrm{~A}$ reduction in rainfall by approximately $10 \%$, as well as increased daytime temperature was attributed to a loss in transpiration and physical evaporation of water from the land. Raddatz ${ }^{103,104}$ also found significant effects of LULCC on thunderstorm activity and maximum temperatures in the Canadian Prairies. Taylor et al. ${ }^{105}$ found that mesoscale variations in soil moisture patterns (which could be due to both antecedent rainfall and also LULCC) significantly influenced Sahelian thunderstorms, and this effect likely occurs everywhere when deep cumulus convection occurs. 


\section{Summary}

This section is by no means inclusive in terms of observational studies that document a major role of LULCC in altering surface fluxes, surface, and near-surface variables, and boundary layer dynamics. However, the evidence for a significant effect of LULCC on climate at local and regional scales is convincing.

Landscape changes affect the regional surface temperature patterns. ${ }^{16,74,99,106-109}$ In contrast to some forcings that basically warm (e.g., greenhouse gases) or cool (e.g., sulphate aerosols), the temperature response to LULCC is multidirectional and depends on the type of change; it may be subject to interactions with soil conditions and can be different for mean versus extreme quantities.

The combined effect of LULCC and snow is also important in terms of surface fluxes and boundary layer structure. ${ }^{110,111}$ Figure 8 illustrates the observed large differences in lower boundary layer thermodynamic stability between a snow-covered grassland and agriculture area and an adjacent snow-free area. The very large stable surface boundary layer over the snow-covered area is a direct result of the much greater reflectance of sunlight when snow is present. The removal of natural vegetation and replacement with shorter vegetation height (or just fallow soil) permits snow to cover the soil more uniformly, resulting in a higher albedo.

\section{Changes in Meso-, Regional- and Global-Scale Atmospheric Conditions Because of Land Use/Land Cover Changes}

Mesoscale and regional weather patterns are hypothesized to change as a result of changes in the surface fluxes, surface and near-surface variables and boundary layer dynamics. ${ }^{6,112-116}$ These modeling-based experiments first assess the skill of the simulations to describe weather with current landscape conditions. Once the level of skill is determined, sensitivity experiments are performed where specified landscape changes are made. This is a type of attribution study in that, if the control experiment (with current landscape is used) agrees closely with the real world, there is confidence that the sensitivity of weather and other aspects of climate to the landscape change are real. An added test of model realism is if the surface fluxes, surface and near-surface variables and 
(a)

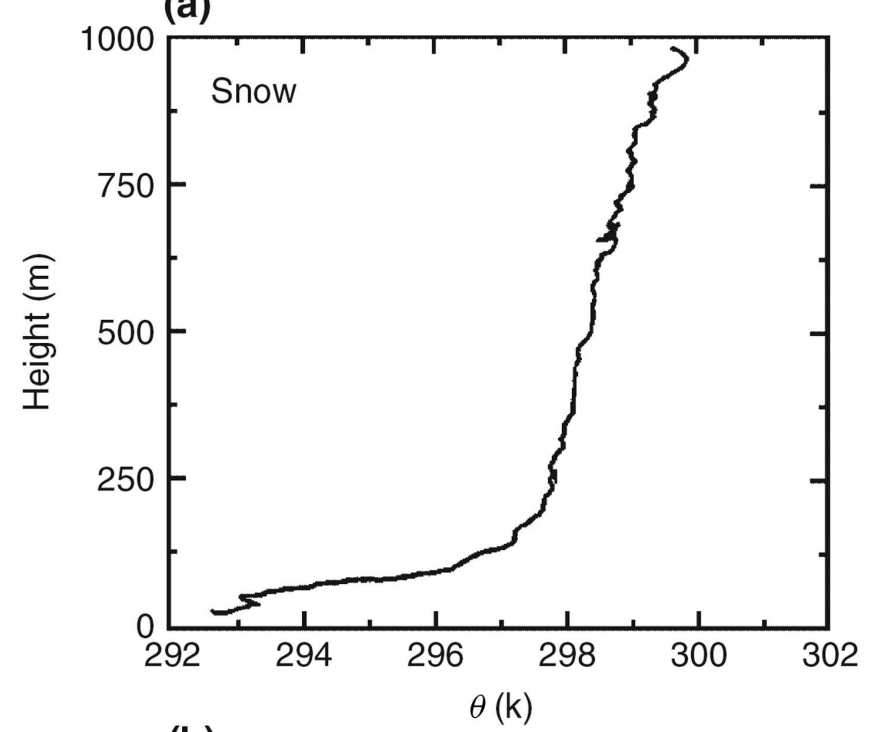

(b)

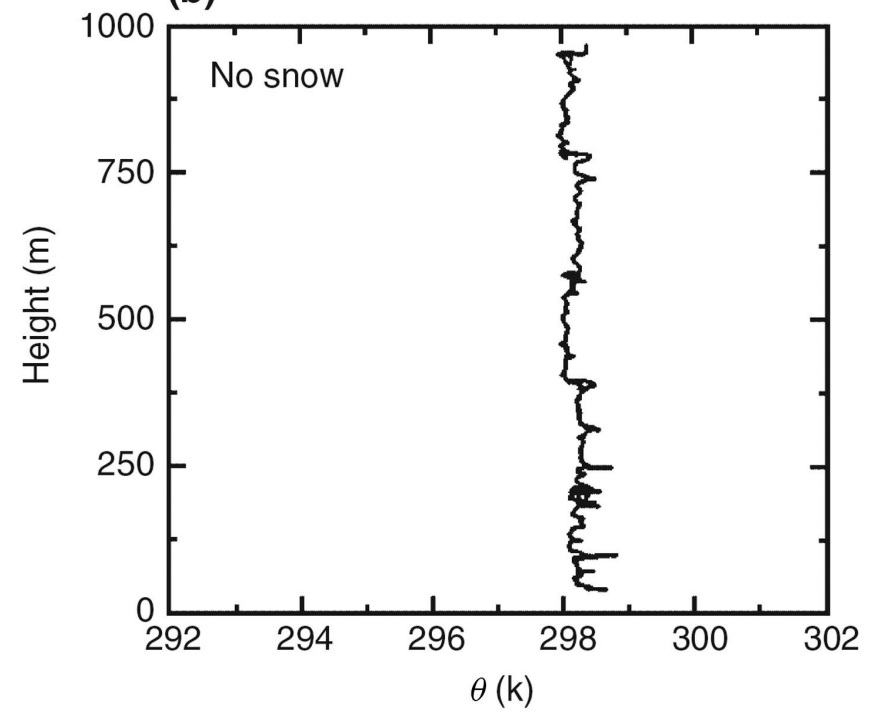

Figure 8 Vertical profiles of several variables from Flight No. 1 over the Arkansas River based on flight altitude data measured at $95 \mathrm{~m}$. Measurements over the snowfree ground were made from 1230:00 to 1257:10 MST. Measurements over the snow were made from 1416:55 to 1435:00 MST. (a) and (b) are for potential temperature. (Reprinted with permission from Ref 110. Copyright 1991 American Meteorological Society)

boundary layer development, simulated by the models, are in agreement with those found from observations. Examples of the effect of LULCC on meso-, regional-, and global-scale atmospheric conditions for several geographic regions are given below. 


\section{USA}

Today, there are about 70,000 dams in the United States. ${ }^{117}$ Using a 30year observational record from the North American Regional Reanalysis, ${ }^{118}$ Degu et al. ${ }^{119}$ recently analyzed the spatial gradients of atmospheric variables around the shorelines of 92 artificial reservoirs in North America. Their study concluded that large dams influenced local climate most in Mediterranean, arid and semiarid climates, with the energy available for deep cumulus convection increasing by 2-3 times during the growing season. Pielke ${ }^{120}$ shows how large increases in this energy at warm temperature scan result from even a dewpoint temperature increase due to LULCC change of just $1{ }^{\circ} \mathrm{C}$. Spatial gradients of specific humidity and surface evaporation were also observed in the region around these dams. When correlated with local rainfall records, an increasing correlation between the potential for deep convection and higher percentile of rainfall (90th and above) at locations closer to the reservoir was also found.

The effect of urbanization on the rainfall pattern has been found to be significant though difficult to detect. ${ }^{121,122}$ Niyogi et al. ${ }^{113}$ analyzed storm climatology and found that thunderstorms alter their morphology by splitting over urban regions. Figure 9 shows an example of a radar reflectivity for a storm approaching the Indianapolis urban area which then splits into two cores as it passes over the city and then reintensifies downwind (Figure 9(a)-(d)). An observational analysis of a decade long storm climatology using image tagging and storm vector motions confirmed this feature as shown in Figure 9 that about $60 \%$ of the daytime storms split and have a smaller size over the urban area and then reconverge to become a more powerful storm downwind. This effect is also seen in the rainfall climatology over the central Indiana region as shown in Figure 9, where the rainfall is heaviest downwind and lowest over the urban region. This provides support for modeling studies ${ }^{116}$ that found impacts from urbanization on the initiation of thunderstorms. Similar results regarding the urban-storm changes have been reported in the observations by Bornstein and Lin, ${ }^{123}$ Rose and Stallin, ${ }^{124}$ and Mote et al. ${ }^{125}$ for the Atlanta urban area; and for the St. Louis metro area by Changnon et al. ${ }^{126}$ Allard and Carelton ${ }^{85}$ found mesoscale associations between land surface properties and convective cloud development during the warm season over the midwestern United States. 
(a)

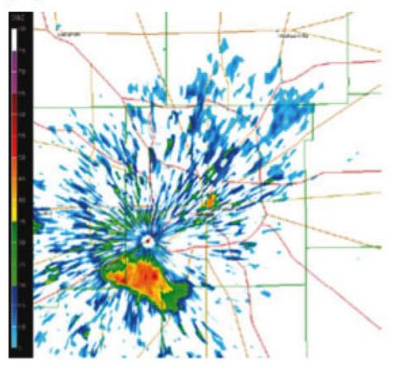

0002 UTC 14 June (b)

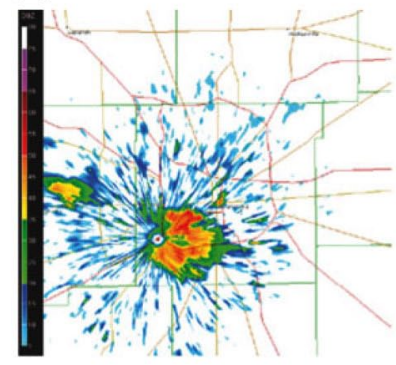

0015 UTC 14 June (d)

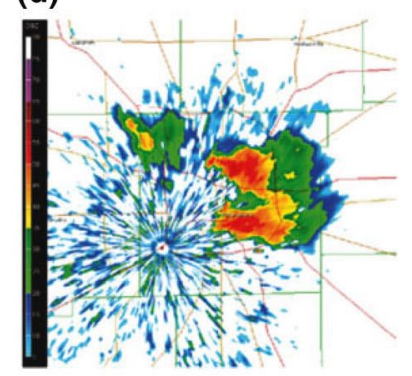

0042 UTC 14 June (e)

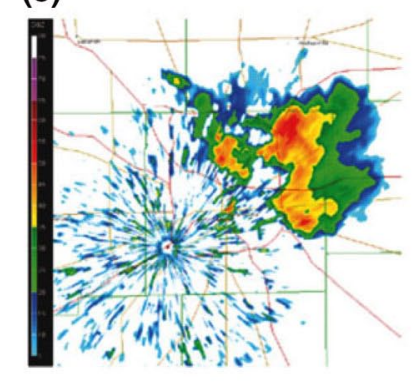

0055 UTC 14 June

Figure 9 Example of a radar reflectivity time sequence showing a storm approaching the Indianapolis urban area in (a) and (b). The storm then splits into two cores as it passes over the city as shown in (c); and then reintensifies downwind ( $d$ and e). (Reprinted with permission from Ref 113. Copyright 2011 American Meteorological Society)

Other studies include Georgescu et al. ${ }^{127}$ who concluded, in a modeling study, that the hypothetical conversion of annual to perennial bioenergy crops across the central United States would impart a significant local to regional cooling with considerable implications for the reservoir of stored soil water. This cooling effect is related mainly to local increases in transpiration, but also to higher albedo. They conclude that the reduction in radiative forcing from albedo alone is equivalent to a carbon emissions reduction of $78 \mathrm{t} \mathrm{Cha}^{-1}$, which is six times larger than the annual biogeochemical effects that arise from offsetting fossil fuel use.

With respect to urbanization, Georgescu et al. ${ }^{128,129}$ found mean regional temperatures in the area centered on Phoenix, Arizona for the circa 2001 landscape were $0.12{ }^{\circ} \mathrm{C}$ warmer than the circa 1973 landscape, with maximum temperature differences, located over regions of greatest urbanization, in excess of $1^{\circ} \mathrm{C}$. 


\section{Australia}

Pitman et al. ${ }^{130}$ using a regional climate model identified a reduction in rainfall in southwest Western Australia coinciding with local areas of land cover change and reduced surface roughness. Narisma and Pit$\operatorname{man}^{131}$ demonstrated a strong impact of land cover change from the natural landscape on surface temperatures in the southeast, southwest, and northeast Australia and a reduction in rainfall of approximately $1 \mathrm{~mm}$ day $^{-1}$ over southwest Australia. Using a multiple-ensemble modeling study, McAlpine et al. ${ }^{132}$ found a statistically significant warming due to historical land cover change during the extended Austral summer (November-March) of $0.1-0.6^{\circ} \mathrm{C}$ in eastern Australia, while mean summer rainfall showed a statistically significant decrease by $4-12 \%$ in southeast Australia. The changes in surface temperature were more coincidental with LULCC than the rainfall. The analysis also showed land cover change contributed to higher summer temperatures during $\mathrm{El} \mathrm{Ni}$ no years, such as the severe drought of $2002 / 2003$. Ornstein et al. ${ }^{133}$ has proposed irrigated afforestation in the Australian (and Saharan) arid regions as a way to alter regional and larger-scale climate.

\section{Asia}

LULCC may alter the intensity of monsoons. ${ }^{114}$ Chang et al. ${ }^{134}$ and Kishtawal et al. ${ }^{135}$ showed that the climatology of the post-landfall rainfall from tropical systems, particularly monsoon depressions which cause nearly $70 \%$ of the heavy rainfall in the Indian monsoon region, are sensitive to the antecedent mesoscale latent heat fluxes over land. Kishtawal et al ${ }^{80}$ reported a LULCC signature in the heavy rainfall climatology over the Indian monsoon region. ${ }^{136}$ The same study also found that only those stations that are influenced by urbanization show an increase in rainfall intensity, while rainfall in the rural regions has remained relatively unchanged. This observation of more intense rainfall in the vicinity of urban areas as compared to nonurban areas was supported by surface-based observations for the 50 year period that were quality controlled and also available through the India Meteorological Department and the more recent Tropical Rainfall Measuring Mission (TRMM) (Figure 10). Zhao ${ }^{137}$ analyzed regional precipitation using TRMM data from 1998 to 2009 for the pre- and post-dam period of the 

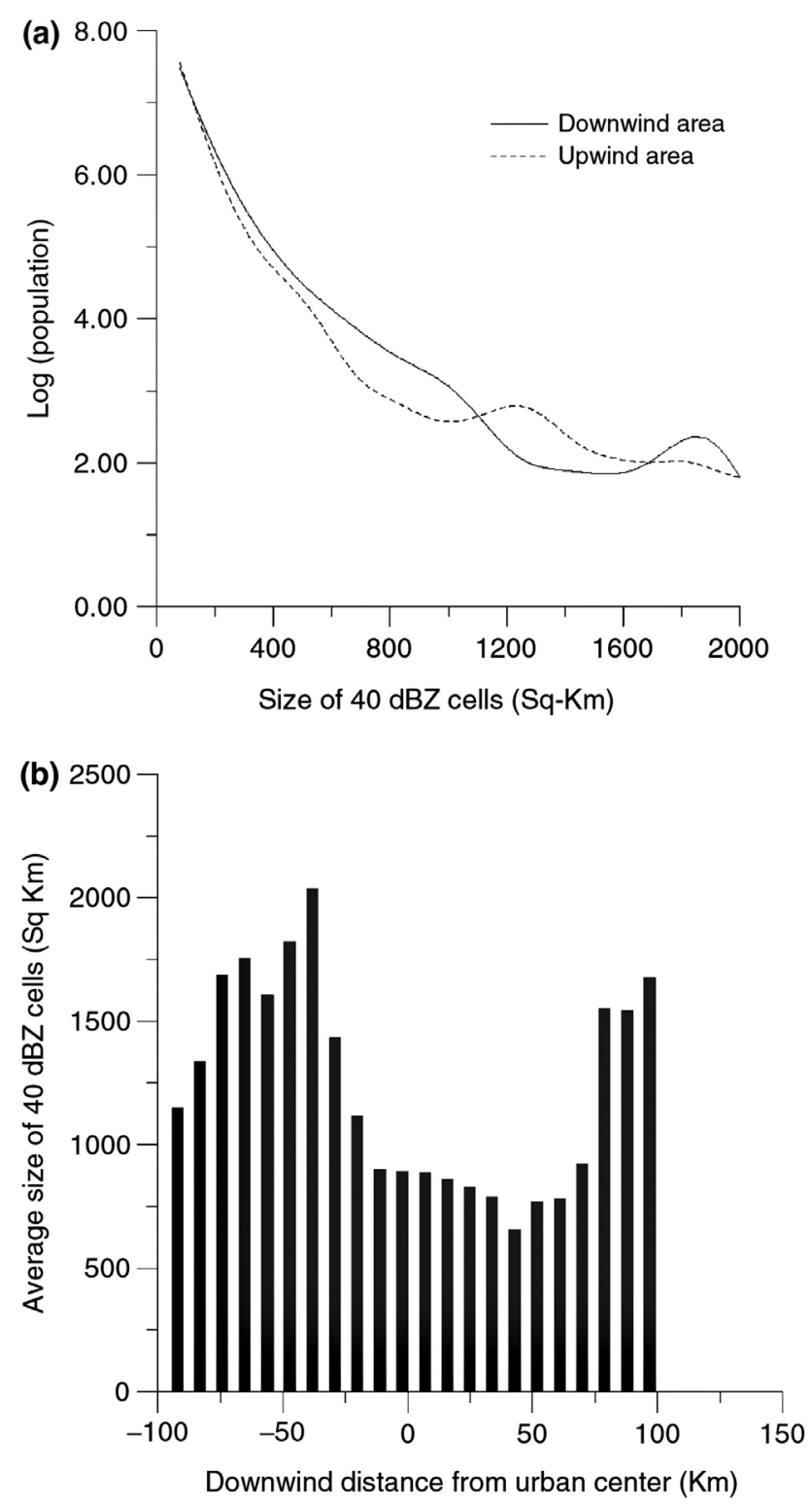

Figure 10 Analysis of a decade long storm climatology using image tagging and storm vector motions showing the splitting of the storms over the urban area and the reemergence of bigger and reintensified downwind. (a) Frequency distribution of storm cells (reflectivity > $40 \mathrm{dBZ}$ ) over the downwind region (solid line) and upwind region (dashed line) from Indianapolis urban area; (b) average size of high-echo cells with downwind distance from Indianapolis urban center. (Reprinted with permission from Ref 113. Copyright 2011 American Meteorological Society)

Three Gorges Dam in China and found that moderate precipitation is greatly reduced in the vicinity of the reservoir, while enhanced on both sides of the reservoir. 


\section{Summary}

The conclusion from these studies is that LULCC can result in mesoscale and regional climate change if the areal coverage of the landscape conversion is large enough. A spatial heterogeneity of approximately 10-20 km has often been considered sufficient for creating mesoscale circulations under convective conditions though smaller scales approximately 2-5 km are also often sufficient to trigger changes in boundary layer dynamics. ${ }^{138-140}$ For the monsoon effects, the threshold may be larger. The irrigation effects for northwest India, for instance, suggest that the required landscape change is probably on the order of 50$100 \mathrm{~km}$ to affect the synoptic convergence patterns. Below this scale of heterogeneity, spatial heterogeneities in the surface fluxes have been assumed to horizontally homogenize below the rest of the boundary layer (e.g., Ref 141).

The reason that spatial scales above a certain threshold are needed is that below this spatial scale, the convective boundary layer or the regional flow is able to homogenize any surface heat flux heterogeneities before they reach very high into the atmosphere. Hadfield et al. ${ }^{142,143} \mathrm{ex}-$ amined this issue with a large eddy simulation model and concluded that there may be a transitional value of the spatial scale of the surface heating heterogeneity between 1500 and $4500 \mathrm{~m}$ above which the circulation is strong enough to organize itself and below which it is not. The effect of LULCC on atmospheric circulations associated with stable boundary layers, however, is more complex. Steenevelt et al. ${ }^{144}$ and Holtslag, ${ }^{145}$ for example, find very large sensitivities in boundary layer temperature structure for even small changes in how they are modeled.

\section{Unanswered Questions}

An important remaining research question is whether the global climate system may be altered as a result of LULCC such as any alteration in the nearly two-thirds of the precipitation that falls over land which is returned to the atmosphere via evaporation. ${ }^{146} \mathrm{Global}$ modeling studies, ${ }^{115}$ while showing significant regional effects of LULCC change, do not simulate substantial changes in the global average radiative forcing. This is due to the finding in the models that areas of positive radiative forcing that result from LULCC are balanced by areas with negative radiative 
forcings. However, this does not mean there is no global climate effect on atmospheric and ocean circulation features. Figure 11 shows the response of seven models to either LULCC or combined changes in added $\mathrm{CO}_{2}$ and sea surface temperatures since preindustrial times, and their spread. It makes the point clear that LULCC is regionally as important as these other two effects.

The evidence that LULCC affects regions that have been subjected to change is very strong, based on observations, modeling, and theory, as we have documented with examples earlier in this article. However, there remains disagreement within the community on whether LULCC causes changes in climate that is remote from the region of land cover change. The large-scale atmospheric patterning that occurs with ENSO, the Pacific Decadal Oscillation (PDO), the North Atlantic Oscillation (NAO), the Arctic Oscillation (AO), the Asian monsoon etc. are the most important large-scale pattern that affects regional weather and climate. However, multidecadal global climate model predictions have not yet rigorously addressed how these circulation features (and if) have changed in response to LULCC. There is evidence that dust from human-degraded landscapes has effects on climate at long distances from its source. ${ }^{148}$ Van der Molen ${ }^{149}$ hypothesizes, based on a model simulation, a pronounced meridional (equator to pole) gradient of climate response to LULCC due to a decrease in cloud cover after deforestation.

There are several problems with how LULCC has been explored in climate models that limit their use in determining whether changes in atmospheric and ocean circulation patterns can be significantly altered at locations that are remote from land cover change. Some examples include:

- Most LULCC experiments use one or two climate models and thus it is hard to determine whether a result is model dependent. We know that models vary in their response to increased $\mathrm{CO}_{2}$; in the same way as the IPCC would not base conclusions on one climate model, we should not base our conclusions of the significance of LULCC on any single model. The nearest the community has come to addressing this limitation is the LUCID (Land Use Change IDentification) experiment ${ }^{21,147}$ and no teleconnections were found, but their experiments were limited in addressing this question due to the use of fixed sea surface temperatures; 
(a)

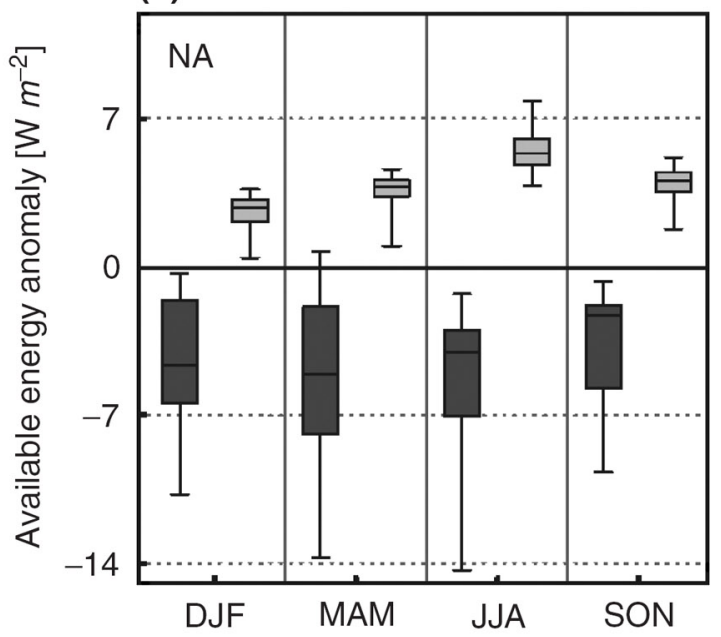

(c)

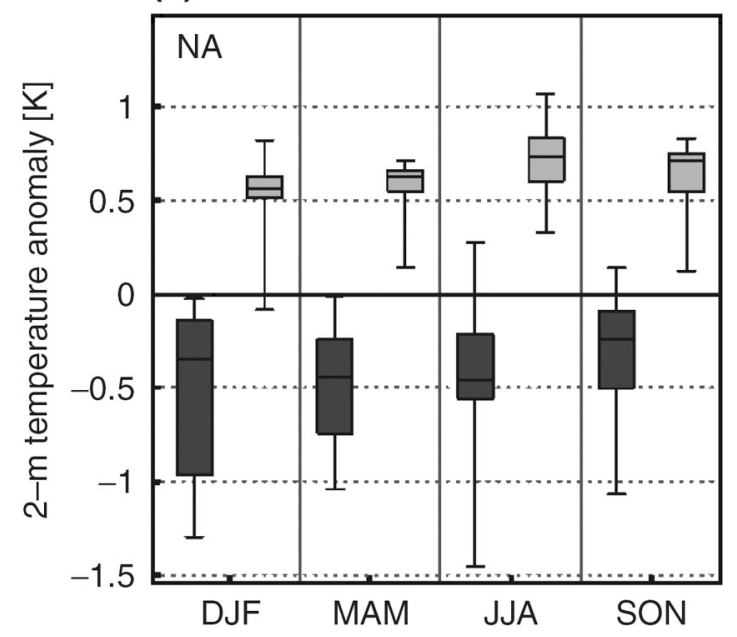

(b)

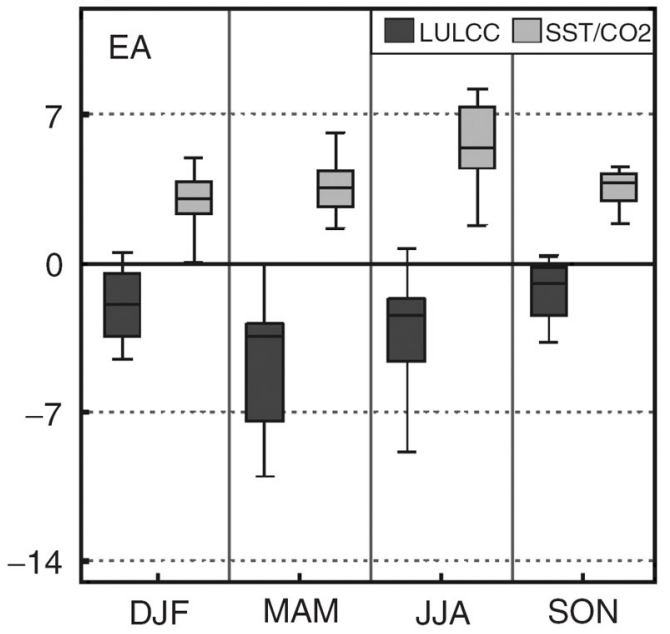

(d)

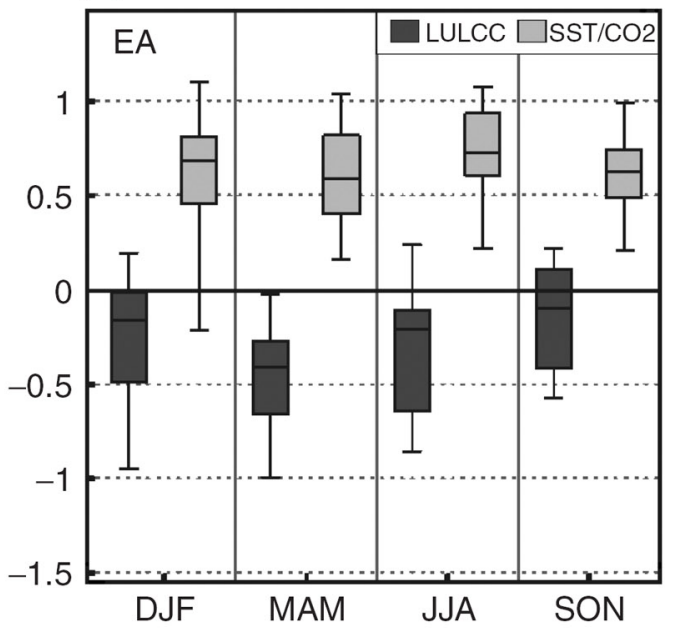

Figure 11 Box and whisker plots of the simulated changes, between the preindustrial time period and present-day, in (a) and (b) available energy ( $\left.\mathrm{W} \mathrm{m}^{-2}\right)$ and (c) and (d) surface air temperature $\left({ }^{\circ} \mathrm{C}\right.$ ) for all seasons and both selected regions (North America: a and c, Eurasia: b and d, see Figure 3 for the definition of the regions). Seven coupled atmosphere/land models were used to draw this graph (LUCID simulations; Pitman et al. ${ }^{21}$; de Noblet-Ducoudré et al. ${ }^{147}$ ). All seven models undertook two sets of two simulations spanning a matrix of present day and preindustrial GHG-concentrations/SSTs, and present day and preindustrial land cover. In these experiments the models are forced with two different vegetation distributions (representative of 1870 or 1992, Figure 3). Each model carried out at least five independent simulations for each experiment to increase the capacity to determine those changes that were robust from those that reflected internal model variability. Values used for the plot are showing the mean ensemble values of each individual model. CO2SST refer to the sole impacts of changes in atmospheric $\mathrm{CO}_{2}$, sea-surface temperature and sea-ice extent between present-day and preindustrial time, while LULCC refer to the sole impact of land cover change between those same time periods. [The bottom and top of the box is the 25th and 75th percentile, and the horizontal line within each box is the 50th percentile (the median). The whiskers (straight lines) indicate the ensemble maximum and minimum values.] 
- Koster et al. ${ }^{150}$ and Seneviratne et al. ${ }^{151}$ showed that the land is coupled to the atmosphere with very different strengths. This may lead to major differences between models in the impact of LULCC. We do not know what the right strength is for any given region;

- Many LULCC experiments have assessed statistical significance using tests that do not take autocorrelation into account (e.g., a student's $t$-test). These can overestimate the significance of a change in the climate ${ }^{152}$ and generate excessive false positives ('false' in a statistical sense);

- Some LULCC simulations still use first generation land surface models $^{13}$ which overestimate the impact of a perturbation ${ }^{78}$ because they do not represent the coupled energy, water and carbon cycles. However, even if state of the art land surface models are used, these still substantially disagree on how to take a change in net radiation and partition it between the sensible and latent heat fluxes. ${ }^{147}$

There are simply still too few statistically rigorous experiments to definitively answer whether LULCC can cause remote changes via teleconnections. Some relatively well-designed experiments ${ }^{13,21,152,153}$ suggest that they do not, while one study ${ }^{154}$ suggests that they do. In general, earlier works that have addressed this question are compromised by the limitations listed above.

\section{Synthesis and Recommendations}

\section{Established Understanding}

LULCC changes the terrestrial carbon balance. In the past, large quantities of $\mathrm{CO}_{2}$ were emitted into the atmosphere as a result of LULCC. This has had a global-scale impact on atmospheric $\mathrm{CO}_{2}$ and through this on the energy balance of the Earth. LULCC also affects the biogeochemical fluxes of many other chemicals ${ }^{154}$ although those impacts have not yet been quantified.

LULCC also has a profound impact on the regional-scale surface energy, trace gas and aerosol, and water balance. Where LULCC has been intensive, the regional impact is likely, in general, to be at least as 
important as greenhouse gas and aerosol forcings. ${ }^{61}$ The fact that the impact of LULCC is small with respect to the global average radiative forcing, with the exception of LULCC related emissions of $\mathrm{CO}_{2}$, is not a relevant metric as the essential resources of food, water, energy, human health, and ecosystem function respond to regional and local climate, not to a global average. Human vulnerability to forcings such as climate change is realized locally and regionally and the conclusion that LULCC is a significant regional-scale driver of climate is sufficient to require its incorporation into past, present, and future climate model simulations.

With LULCC increasingly forming part of climate change mitigation strategies, the wider effects of LULCC on climate over and above carbon emissions/ uptake need to be considered with appropriate metrics which go beyond the simple radiative-forcing based metrics such as Global Warming Potentials. ${ }^{155}$ Moreover, consideration of LULCC effects is increasingly important as the requirement to adapt to ongoing climate change and variability is rising rapidly on the international policy agenda as well as growing in the awareness of other actors such as industry, local government, and individuals. ${ }^{156}$

\section{Remaining Uncertainties}

Systematic assessments of the impacts of LULCC on the atmosphere, coincident with regions of intensive LULCC, in comparison to other known climate forcings have not been undertaken. While it is hard to comprehend that irrigation would not cool locally, or urbanization warm locally, or tropical deforestation not warm locally, the magnitude of these impacts relative to say a doubling of atmospheric $\mathrm{CO}_{2}$ is not well known and whether a warming or cooling signal due to LULCC can be sustained for long enough periods to significantly enhance or suppress climate effects due to other forcings including $\mathrm{CO}_{2}$ is not known. Also of importance, but even less well known or studied, is the relative role of LULCC to the other human climate forcings in altering the large-scale atmospheric/ ocean modes of variability including its interaction with ENSO, the PDO, the NAO, AO, monsoon, etc. While LULCC may not affect these modes of variability, given how important they are in the provision of food, water, and ecosystem function, it is remarkable how little effort has been invested in exploring potential links between LULCC, the modes of variability and impacts on human systems. 
In terms of simulating the impacts of LULCC, the LUCID project ${ }^{147}$ has demonstrated that the land surface community is not well prepared for the challenges of simulating this forcing in climate models. It is clear that the community has to explicitly parameterize crops, open water, irrigation, urban landscapes, and heterogeneity (tiling) for our models to capture the regional impacts of LULCC. However, despite many years of the land surface community identifying this need, LULCC remains a relatively low priority in most climate-modeling groups, although the results from these climate models are being used over regions of substantial LULCC. Moreover, the increase in spatial resolution of climate models makes the importance of correct simulation of climate impacts of LULCC even more vital.

However, we need a better understanding as to what spatial scale and type LULCC and surface-atmosphere interaction matters in terms of a climate impact. We do know, for example, that snow cover provides an amplification of LULCC through its large alteration in surface heat fluxes. ${ }^{157}$ Koster et al. ${ }^{150}$ identified particularly strong land-atmospheric interactions with respect to spatial scale and geographic location.

We still do not know if global-scale teleconnections may result from LULCC. We hypothesize from models that they are possible but LUCID showed that models did not agree on such remote impacts. Moreover, the assessments by the IPCC show considerable regional divergence from a given forcing so it is premature to conclude that LULCC does [or does not] trigger remote effects. A problem is that many largescale modeling experiments have used a 'scorched Earth' strategy on LULCC (converting the Amazon into a manicured lawn). While such a change might trigger an impact it is not a realistic perturbation and thus hard to interpret.

We also do not know if we can parameterize LULCC in our land surface models with appropriate skill. Few models explicitly represent the set of important plant functional types, phenology, irrigation, dams and reservoirs, and urban landscapes, and those that do would not claim they do them "right." 158 Rigorous experiments that impose realistic LULCC and evaluates how each climate model responds is clearly needed.

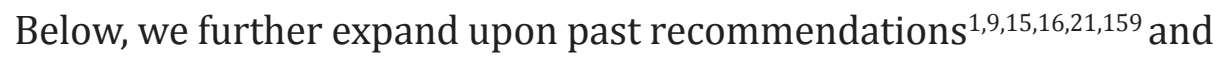
propose a series of tasks to resolve these unknowns. 


\section{Challenges}

1. New data sets targeting LULCC: Longitudinal observational studies such as those conducted over Western Australia or the global network of eddy covariance stations within FLUXNET have genuinely helped resolve some major questions. There are few data sets designed to provide very similar atmospheres over crops and forests in boreal and temperate regions. These would be extremely valuable to test how models capture LULCC impacts on weather. A challenge with respect to detecting a signal in the observations from LULCC is the time scale needed to extract a signal (decades and longer). Only where LULCC change is rapid and extensive will such observational testing be feasible. However, even here, while detecting the impact of LULCC on local and regional climate may be relatively straightforward, correctly attributing impacts on the large-scale circulation will remain challenging.

2. Agreed LULCC implementation protocol for land surface models is required: Replacing $10 \%$ of a region with crops can mean removal of $10 \%$ tree cover, or replacement of $10 \%$ grass with crops or some combination. To compare LULCC experiments, modelers need to report how they implemented land cover change in considerably more detail. Further challenges include representing crop phenology in land surface models since some models do, some do not, some prescribe phenology, while others predict the responses, and these all affect how LULCC is implemented.

3. New LSM Evaluation: A rigorous evaluation of land surface-models uncoupled from the host climate-models (i.e., offline) needs to be conducted. Do land surface models capture the contrast between natural and anthropogenic land cover? Can they simulate crops, the regrowth after deforestation, and other significant processes? Do they properly simulate the impact of LULCC on fluxes? Offline skill in capturing the impact of LULCC is a necessity if the model is to capture the impact in a coupled model; it is however an insufficient criterion and can only be a first step in any systematic evaluation of the impact of LULCC on climate.

4. Agree on realistic scenarios for past LULCC and reasonable scenarios for future change: This includes agreed LULCC implementation 
methods-reporting what is changed, how, and what was replaced for comparing model experiments. This calls for a standard change matrix and framework for comparing, analyzing, synthesizing, and presenting LULCC studies so that the results are transferable.

5. Multiple models; multiple realizations: Multiple realizations (simulations with the same model with perturbed initial conditions) are required to allow the signal from LULCC to be identified against background natural variability. If transitory experiments are conducted, then the number of realizations likely has to exceed ten. Proven high-skill models or multiple models should also be used, with current versions of a given climate model used to allow the role of LULCC to be compared with $\mathrm{CO}_{2}$. When using regional models, the model domain of the LULCC experiments needs to extend well beyond the region of LULCC. The lateral boundary of the model domain needs to be large enough for large-scale circulation to develop and influence regional weather systems. ${ }^{160-162}$

6. Extremes as well as means: We need to explore the impact of LULCC on both the mean climate and climatic extremes such as very hot days and droughts.

7. Changes in large-scale atmospheric and ocean circulations: Possible changes in major circulation features such as ENSO, the PDO, etc. resulting from LULCC using multiple long-term ensemble experiments with proper statistical testing (e.g., bootstrapping) are needed. It is these weather features that produce such societally important events such as droughts and floods. ${ }^{163}$

8. Relative to something: A climate model's sensitivity to LULCC needs to be placed in context. A much better baseline than global radiative forcing as a means for assessing and faithfully representing the regionally diverse and multidirectional effects of LULCC is needed. ${ }^{2}$ There are several simple sensitivity experiments that could be performed to determine the models' background response to a perturbation but the simplest would be to first know the impact of a doubling of $\mathrm{CO}_{2}$ in the model. It is important to obtain this signal with precisely the same model as is used for a LULCC experiment. This should be conducted with fully coupled models in order to obtain an assessment of climate responses as related to the existing IPCC estimates. Also, it would be valuable to determine the climate model's response to known ENSO-like sea surface temperature 
anomalies. ${ }^{154}$ Teleconnection patterns from ENSO are quite well known and a model must be able to skillfully simulate such circulation features. If a climate model well captures teleconnections induced by an ENSO anomaly, given it's a tropical anomaly, then teleconnections induced in the same model by a tropical anomaly caused by LULCC should be equally realistic.

9. REDD: There is a need to broaden the REDD [Reduced Emissions from Deforestation and forest Degradation) program of the United Nations - http://www.un-redd.org — framework to include biogeophysical change effects. REDD seeks to reduce greenhouse emissions from deforestation and forest degradation, particularly in tropical countries where forest carbon pools are large.

Clearly, an effort to address LULCC with the requirements of (a) through ( $\mathrm{g}$ ) will be an enormous undertaking. However, it is clear that LULCC does directly affect regional climates that have seen intensive LULCC. These regions include parts of North America, Europe, China, and India with several billion humans.

For those regions that have undergone intensive LULCC, or will undergo intensive change in the future, failure to factor in this forcing has profound consequences. Investments in adapting to ongoing humaninduced climate change and natural variability will remain founded on incomplete and potentially misleading information. This in turn leads to a higher risk of misaligned investment in climate adaptation, which is a vastly more expensive outcome than the costs of resolving the impact of LULCC on the Earth's global and regional climate. Unless we undertake a thorough assessment of the role of LULCC on climate, an incomplete understanding of the role of humans in the climate system will persist.

Acknowledgments Dallas Staley completed the final editing of the paper with her standard outstanding work. We thank Dallas for her commitment to excellence. Roger Pielke Sr. acknowledges support from NSF Grant ATM-0831331. Dev Niyogi benefitted from NSF CAREER (AGS-0847472, Anjuli Bamzai), NASA LCLUC and NASA THP (NNX08AV80G, Jared Entin and Garik Gutman), DOE ARM (08ER64674, Rick Petty). Clive McAlpine is supported by the Australian Research Council FT100100338. Andy Pitman is supported by the Australian Research Council CE11E0098. The authors also gratefully acknowledge the discussions, input and collaboration among the participants of the NASA LULCC initiative, IGBP 2nd Synthesis topic on 'Land-use-induced land-cover changes and the functioning of the Earth System.' 


\section{References}

1. Kabat P, Claussen M, Dirmeyer PA, Gash JHC, Bravo de Guenni L, Meybeck M, Pielke RA, Sr., Vorosmarty CJ, Hutjes RWA. In: Lutkemeier S, ed. Vegetation, Water, Humans and the Climate: A New Perspective on an Interactive System, Global Change-The IGBP Series. Berlin: Springer; 2004, 566.

2. National Research Council. Radiative forcing of climate change: expanding the concept and addressing uncertainties. Committee on Radiative Forcing Effects on Climate Change, Climate Research Committee, Board on Atmospheric Sciences and Climate, Division on Earth and Life Studies. Washington, DC: The National Academies Press; 2005, 208.

3. http://www.ametsoc.org/policy/2010inadvertentweather mod amsstatement. html (Accessed May 15, 2011).

4. Williams M. Forests In: Turner BL, Clark RW, Kates RW, Richards JF, Mathews JT, Meyer WB, eds. The Earth as Transformed by Human Action. Cambridge: Cambridge University Press; 1990, 179-201.

5. Meyer WB, Turner BL, II. Changes in Land Use and Land Cover: A Global Perspective. New York: Cambridge University Press; 1994.

6. Cotton WR, Pielke RA, Sr. Human Impacts on Weather and Climate. New York: Cambridge University Press; 2007, 330.

7. Pielke RA, Sr. Climate prediction as an initial value problem. Bull Am Meteorol Soc 1998, 79:2743-2746.

8. Pielke RA, Sr., Marland G, Betts RA, Chase TN, Eastman JL, Niles JO, Niyogi D, Running $\mathrm{S}$. The influence of land-use change and landscape dynamics on the climate system-relevance to climate change policy beyond the radiative effect of greenhouse gases. Phil Trans A 2002, 360:1705-1719. doi:10.1098/ rsta.2002.1027.

9. Pielke RA, Sr., Adegoke J0, Chase TN, Marshall CH, Matsui T, Niyogi D. A new paradigm for assessing the role of agriculture in the climate system and in climate change. Agric Forest Meteorol 2007, 132:234-254. doi:10.1016/j. agrformet.2006.06.012.

10. Pielke RA, Sr, Adegoke J, Beltran-Przekurat A, Hiemstra CA, Lin J, Nair US, Niyogi D, Nobis TE. An overview of regional land use and land cover impacts on rainfall. Tellus B 2007, 59:587-601. doi:10.1111/j.1600-0889.2007.00251.x.

11. Bonan G. Ecological Climatology: Concepts and Applications. Cambridge: Cambridge University Press; 2002, 678.

12. Arora VK. Modelling vegetation as a dynamic component in soil-vegetationatmosphere-transfer schemes and hydrological models. Rev Geophys 2002, 40:1006. doi:10.1029/2001RG000103

13. Pitman AJ. The evolution of, and revolution in, land surface schemes designed for climate models. Int J Climatol 2003, 23:479-510. doi:10.1002/joc.893. 
14. McAlpine CA, Ryan JG, Seabrook LM, Thomas S, Dargusch PJ, Syktus JI, Pielke RA, $\mathrm{Sr}$., Etter AE, Fearnside PM, Laurance WF. More than $\mathrm{CO}_{2}$ : a broader picture for managing climate change and variability to avoid ecosystem collapse. Curr Opin Environ Sustain 2010, 2:334-336. doi:10.1016/j.cosust.2010.10.001.

15. Dirmeyer PA, Guo Z, Wei J. Building the case for (or against) land-driven climate predictability. iLEAPS Newslett 2010, 9:14-17.

16. Mahmood R, Pielke RA, Sr., Hubbard KG, Niyogi D, Bonan G, Lawrence P, Baker B, McNider R, McAlpine C, Etter A, et al. Impacts of land use land cover change on climate and future research priorities. Bull Am Meteorol Soc 2010, 91:37-46. doi:10.1175/2009BAMS2769.1.

17. Dirmeyer PA, Niyogi D, de Noblet-Ducoudré N, Dickinson RE, Snyder PK. Impacts of land use change on climate. Int J Climatol 2010, 30:1905-1907. doi:10.1002/ joc. 2157.

18. Forster P, Ramaswamy V, Artaxo P, Berntsen T, Betts R, Fahey DW, Haywood J, Lean J, Lowe DC, Myhre G, et al. Radiative forcing of climate change. In: Solomon S, Qin D, Manning M, Chen Z, Marquis M, Averyt KB, Tignor M, Miller HL, eds. Climate Change 2007: The Physical Science Basis. Contribution of Working Group I to the Fourth Assessment Report of the Intergovernmental Panel on Climate Change. Cambridge and New York, NY: Cambridge University Press; 2007, 129-234.

19. Pielke RA, Sr., Niyogi D. The role of landscape processes within the climate system. In: Otto J-C, Dikau R, eds. Landform-Structure, Evolution, Process Control, Lecture Notes in Earth Sciences. Berlin, Heidelberg: Springer-Verlag; 2010, 67-85.

20. Betts AK, Ball JH, Beljaars ACM, Miller MJ, Viterbo P. The land-surfaceatmosphere interaction: a review based on observational and global modeling perspectives. J Geophys Res 1996, 101:7209-7225.

21. Pitman AJ, de Noblet-Ducoudré N, Cruz FT, Davin EL, Bonan GB, Brovkin V, Claussen M, Delire C, Ganzeveld L, Gayler V, et al. Uncertainties in climate responses to past land cover change: first results from the LUCID intercomparison study. Geophys Res Lett 2009, 36:L14814. doi:10.1029/2009GL039076.

22. Betts RA. Offset of the potential carbon sink from boreal forestation by decreases in surface albedo. Nature 2000, 408:187-190. doi:10.1038/35041545.

23. Stohlgren TJ. Measuring Plant Diversity Lessons from the Field. New York: Oxford University Press; 2007, 390.

24. Ramankutty N, Foley JA. Estimating historical changes in global land cover: Croplands from 1700 to 1992. Global Biogeochem Cycles 1999, 13:997-1027. doi:10.1029/1999GB900046.

25. Klein Goldewijk K. Estimating global land use change over the past 300 years: the HYDE database. Global Biogeochem Cycles 2001, 15:417-434. doi:10.1029/2000GB001290. 
26. DeFries R, Field CB, Fung I, Justice CO, Matson PA, Matthews M, Mooney HA, Potter CS, Prentice K, Sellers PJ, et al. Mapping the land surface for global atmosphere biosphere models: toward continuous distributions of vegetation's functional properties. Journal of Geophysical Research 1995, 100.867-882. doi:10.1029/95JD01536.

27. Hurtt GC, Frolking S, Fearon MG, Moore III B, Shevliakova E, Malyshev S, Pacala S, Houghton RA. The underpinnings of land-use history: three centuries of global gridded land-use transitions, wood harvest activity, and resulting secondary lands. Global Change Biol 2006, 12:1-22. doi:10.1111/j.1365-2486.2006.01150.x.

28. Pongratz J, Reick C, Raddatz T, Claussen M. A reconstruction of global agricultural areas and land cover for the last millennium. Global Biogeochem Cycles 2008, 22:GB3018. doi:10.129/2007GB003153.

29. Klein Goldewijk K, Beusen A, Janssen P. Long term dynamic modeling of global population and built-up area in a spatially explicit way, HYDE 3.1. Holocene 2010, 20:565-573. doi:10.1177/0959683609356587.

30. Klein Goldewijk K, Beusen A, van Drecht G, de Vos M. The HYDE 3.1 spatially explicit database of human induced land use change over the past 12,000 years. Global Ecol Biogeograph 2011, 20:73-86 doi:10.1111/j.1466-8238.2010.00587.x.

31. Richards JF. In: Turner BL, ed. Land Transformation. The Earth as Transformed by Human Action. New York: Cambridge University Press; 1990, 163-178.

32. Matthews E. Global vegetation and land use: new high-resolution data bases for climate studies. J Clim Appl Meteorol 1983, 22:474-487. 10.1175/1520-0450(1983)022<0474:GVALUN>2.0.CO;2.

33. Biemans H, Haddeland I, Kabat P, Ludwig F, Hutjes RWA, Heinke J, von Bloh W, Gerten D. Impact of reservoirs on river discharge and irrigation water supply during the 20th century. Water Resour Res 2011, doi:10.1029/2009WR008929.

34. Siebert S, Döll P, Hoogeveen J, Faures JM, Frenken K, Feick S. Development and validation of the global map of irrigation areas. Hydrol Earth Syst Sci 2005, 9:535-547. doi:10.5194/hess-9-535-2005.

35. Potere D, Schneider A. A critical look at representation of urban areas in global maps. Geojournal 2007, 69:55-80. doi:10.1007/s10708-007-9102-z.

36. Williams M. Dark ages and dark areas: global deforestation in the deep past. $J$ Hist Geog 2000, 26:28-46. doi:10.1006/jhge.1999.0189.

37. Mather AS. Global Forest Resources. 1st ed. London: Belhaven Press; 1990.

38. Steyaert LT, Knox RG. Reconstructed historical land cover and biophysical parameters for studies of land-atmosphere interactions within the eastern United States. J Geophys Res 2008, 113:D02101. doi:10.1029/2006JD008277.

39. Urquhart M, Buckley K. Historical Statistics of Canada, Cambridge: Cambridge University Press; 1965. 
40. Grigg D. The industrial revolution and land transformation. In: Wolman MG, Fournier FGA, eds. Land Transformation in Agriculture. Chichester, New York, Brisbane, Toronto, Singapore: John Wiley \& Sons; 1987, 79-109.

41. Etter A, McAlpine C, Possingham H. A historical analysis of the spatial and temporal drivers of landscape change in Colombia since 1500. Ann Assoc Am Geog 2008, 98:1-27.

42. FAO, FAOSTAT. Food and Agriculture Organization of the United Nations, Rome, Italy, 2008. Available at: http://www.fao.org (Accessed October 7, 2011).

43. Richards JF, Flint EP. Historic Land Use and Carbon Estimates for South and Southeast Asia 1880-1980. Carbon Dioxide Information Analysis Center, Oak Ridge National Laboratory, Environmental Sciences Division; 1994, Publication No. 4174.

44. Hobbs RJ, Hopkins AJM. From frontier to fragments: European impact on Australia's vegetation. Proc Ecol Soc Aust 1990, 16:93-114.

45. Grigg DB. The Agricultural Systems of The World: An Evolutionary Approach. New York: Cambridge University Press; 1974.

46. Houghton RA, Hobbie JE, Melillo JM, Moore B, Peterson BJ, Shaver GR, Woodwell GM. Changes in the carbon content of terrestrial biota and soils between 1860 and 1980: A net release of $\mathrm{CO}_{2}$ to the atmosphere. Ecol Monograph 1983, 53:236-262. doi:10.2307/1942531.

47. Seabrook L, McAlpine CA, Fensham R. Cattle, crops and clearing: regional drivers of landscape change in the Brigalow Belt, Queensland, Australia, 1840-2004. Landscape Urban Plann 2006, 78:373-385. doi:10.1016/j. landurbplan.2005.11.007.

48. Lepers E, Lambin EF, Janetos AC, DeFries R, Achard F, Ramankutty N, Scholes RJ. A synthesis of information on rapid land-cover change for the period 19812000. Bioscience 2005, 55:115-124.

49. Andreae MO, Artaxo P, Brandão C, Carswell FE, Ciccioli P, da Costa AL, Culf AD, Esteves JL, Gash JHC, Grace J, et al. Biogeochemical cycling of carbon, water, energy, trace gases and aerosols in Amazonia: the LBA-EUSTACH experiments. J Geophys Res 2002, 107:8066. doi:10.1029/2001JD000524.

50. Luyssaert S, Schulze E-D, Börner A, Knohl A, Hessenmöller D, Law BE, Ciais P, Grace J. Old-growth forests as global carbon sinks. Nature 2008, 455:213-215. doi:10.1038/nature07276.

51. Schulze ED, Kelliher FM, Körner C, Lloyd J, Leuning R. Relationships among maximum stomatal conductance, ecosystem conductance, carbon assimilation rate, and plant nitrogen nutrition: a global ecology scaling exercise. Ann Rev Ecol Syst 1994, 25:629-660.

52. Farquhar GD, Sharkey TD. Stomatal conductance and photosynthesis. Ann Rev Plant Physiol 1982, 33:317-345. doi:10.1146/annurev.pp.33.060182.001533. 
53. Houghton RA, Hackler JL, Lawrence KT. The U.S. carbon budget: contributions from land-use change. Science 1999, 285:547-578. doi:10.1126/ science.285.5427.574.

54. Fearnside PM. Global warming and tropical land-use change: greenhouse gas emissions from biomass burning, decomposition and soils in forest conversion, shifting cultivation and secondary vegetation. Clim Change 2000, 46:115-158. doi:10.1023/A:1005569915357.

55. Post WM, Kwon KC. Soil carbon sequestration and land-use change: processes and potential. Global Change Biol 2000, 6:317-327. doi:10.3334/CDIAC/ tcm.009.

56. Schulze ED, Luyssaert S, Ciais P, Freibauer A, Janssens IA, Soussana JF, Smith P, Grace J, Levin I, Thiruchittampalam B, et al. Importance of methane and nitrous oxide for Europe's terrestrial greenhouse-gas balance. Natl Geosci 2009, 2:842850. doi:10.1038/ngeo686.

57. Gash JHC, Nobre CA. Climatic effect of Amazonian deforestation: some results from ABRACOS. Bull Am Meteorol Soc 1997, 78:823-830. doi:10.1175/1520-0477(1997)078<0823:CEOADS>2.0.C0;2.

58. Silva Dias MAF, Rutledge S, Kabat P, Silva Dias PL, Nobre C, Fisch G, Dolman AJ, Zipser E, Garstang M, Manzi AO, et al. Cloud and rain processes in a biosphereatmosphere interaction context in the Amazon region. J Geophys Res 2002, 107:D20. doi:10.1029/2001JD000335.

59. Wang J, Chagnon FJF, Williams ER, Betts AK, Renno NO, Machado LAT, Bisht G, Knox R, Bras RL. Impact of deforestation in the Amazon basin on cloud climatology. Proc Natl Acad Sci 2009, 106:3670-3674. doi:10.1073/ pnas.0810156106.

60. Souza EP, Rennó NO, Silva Dias MAF. Convective circulations induced by surface heterogeneities. J Atmos Sci 2000, 57:2915-2922. doi:10.1175/1520-0469(2000)057<2915:CCIBSH>2.0.CO;2.

61. Loarie SR, Lobell DB, Asner GP, Field CB. Land-cover and surface water change drive large albedo increases in South America. Earth Interact 2011, 15:1-16. doi:10.1175/2010EI342.1.

62. Beltran-Przekurat A, Pielke RA, Sr., Eastman JL, Coughenour MB. Modeling the effects of land-use/ land-cover changes on the near-surface atmosphere in southern South America. Int J Climatol 2011, doi:10.1002/joc.2346.

63. Butt N, de Oliveira PA, Costa MA. Evidence that deforestation affects the onset of the rainy season in Rondonia, Brazil. J Geophys Res 2011, 116:D11120. doi:10.1029/2010JD015174.

64. Teuling AJ, Seneviratne SI, Stöckli R, Reichstein M, Moors E, Ciais P, Luyssaert $\mathrm{S}$, van den Hurk B, Ammann C, Bernhofer C, et al. Contrasting response of European forest and grassland energy exchange to heatwaves. Nature Geosci 2010, 3:722-727. doi:10.1038/NGE0950. 
65. Baldocchi D, Liukang X. What limits evaporation from Mediterranean oak woodlands - the supply of moisture in the soil, physiological control by plants or the demand by the atmosphere? Adv Water Resour 2007, 30:2113-2122. doi:10.1016/j.advwatres.2006. 06.013.

66. Bonan GB. Forests and climate change: forcings, feedbacks, and the climate benefits from the forests. Science 2008, 320:1444-1449. doi:10.1126/ science.1155121.

67. Lyons TJ, Schwerdtfeger P, Hacker JM, Foster IJ, Smith RCG, Huang $\mathrm{XM}$. Land atmosphere interaction in a semiarid region-the bunny fence experiment. Bull Am Meteorol Soc 1993, 74:1327-1334. doi:10.1175/1520-0477(1993)074<1327:LIIASR>2.0.CO;2.

68. Lyons TJ, Nair US, Foster IJ. Clearing enhances dust devil formation. J Arid Environ 2008, 72:1918-1928. doi:10.1016/j.jaridenv.2008.05.009.

69. Ray DK, Nair US, Welch RM, Han Q Zeng J, Su W, Kikuchi T, Lyons TJ. Effects of land use in southwest Australia: 1. Observations of cumulus cloudiness and energy fluxes. J Geophys Res 2003, 108:4414-4434. doi:10.1029/2002JD002654.

70. Nair US, Wu Y, Kala J, Lyons TJ, Pielke RA, Sr., Hacker JM. The role of land use change on the development and evolution of the west coast trough, convective clouds, and precipitation in southwest Australia. J Geophys Res 2011, 116:D07103. doi:10.1029/2010JD014950.

71. Lyons TJ. Clouds prefer native vegetation. Meteorol Atmos Phys 2002, 80:131140. doi:10.1007/s007030200020.

72. Gordon LJ, Steffen W, Jonsson BF, Folke C, Falkenmark M, Johannessen A. Human modifications of global water vapor flows from the land surface. Proc Natl Acad Sci 2005, 102:7612-7617. doi:10.1073/pnas.0500208102.

73. Rodell M, Velicogna I, Famiglietti JS. Satellite-based estimates of groundwater depletion in India. Nature 2009, 460:999-1002. doi:10.1038/nature08238.

74. Roy SS, Mahmood R, Niyogi D, Lei M, Foster SA, Hubbard KG, Douglas E, Pielke RA, Sr. Impacts of the agricultural Green Revolution induced land use changes on air temperatures in India. J Geophys Res 2007, 112:D21108. doi:10.1029/2007JD008834.

75. Roy SS, Mahmood R, Quintanar AI, Gonzalez A. Impacts of irrigation on dry season precipitation in India. Theoret Appl Climatol 2010, 104:193-207. doi:10.1007/s00704-010-0338-z.

76. Niyogi D, Kishtawal CM, Tripathi S, Govindaraju RS. Observational evidence that agricultural intensification and land use change may be reducing the Indian Summer Monsoon rainfall. Water Resour Res 2010, 46:3. doi:10.1029/2008WR007082.

77. Lee E, Chase TN, Rajagopalan B, Barry RG, Biggs TW, Lawrence PJ. Effects of irrigation and vegetation activity on early Indian summer monsoon variability. Int J Climatol 2009, 29:573-581. doi:10.1002/joc.1721. 
78. Chen T-C, Wang S-Y, Yen M-C. Enhancement of afternoon thunderstorm activity by urbanization in a valley: Taipei. J Appl Meteorol Climatol 2007, 46:1324-1340. doi:10.1175/JAM2526.1.

79. Zhou L, Dickinson RE, Tian Y, Fang J, Li Q, Kaufman RK, Tucker CJ, Myneni RB. Evidence for a significant urbanization effect on climate in China. Proc Natl Acad Sci 2004, 101:9540-9544. doi:10.1073/pnas.0400357101.

80. Kishtawal CM, Niyogi D, Tewari M, Pielke RA, Sr., Shepherd JM. Urbanization signature in the observed heavy rainfall climatology over India. Int J Climatol 2010, 30:1908-1916. doi:10.1002/joc.2044.

81. Strack JE, Pielke RA, Sr., Steyaert LT, Knox RG. Sensitivity of June near-surface temperatures and precipitation in the eastern United States to historical land cover changes since European settlement. Water Resour Res 2008, 44:W11401. doi:10.1029/2007WR00654.

82. Raymond WH, Rabin RM, Wade GS. Evidence of an agricultural heat island in the lower Mississippi River floodplain. Bull Am Meteorol Soc 1994, 75:1019-1025. doi:10.1175/1520-0477(1994)075<1019:EOAAHI>2.0.CO;2.

83. Rabin RM, Martin DW. Satellite observations of shallow cumulus coverage over the central United States: an exploration of land use impact on cloud cover. $J$ Geophys Res 1996, 101:7149-7155.

84. Rabin RM, Stadler SJ, Wetzel PJ, Stensrud DJ, Gregory M. Observed effects of landscape variability on convective clouds. Bull Am Meteorol Soc 1990, 71:272280. doi:10.1175/2010JAS3604.1.

85. Allard JM, Carleton AM. Mesoscale associations between Midwest land-surface properties and convective cloud development in the warm season. Phys Geograph 2010, 31:107-136.

86. Carleton AM, Travis D, Arnold D, Brineger R, Jelinski D, Easterling D. Climaticscale vegetation-cloud interactions during drought using satellite data. Int J Climatol 1994. 14:593-623. doi:10.1002/joc.3370140602.

87. Carleton AM, Adegoke J, Allard J, Arnold DL, Travis DJ. Summer season land cover-convective cloud associations for the Midwest U.S. "Corn Belt". Geophys Res Lett 2001, 28:1679-1682. doi:10.1029/2000GL012635.

88. Carleton AM, Travis DJ, Adegoke JO, Arnold DL, Curran S. Synoptic circulation and land surface influences on convection in the Midwest U.S. "Corn Belt" during the summers of 1999 and 2000. Part II: role of vegetation boundaries. J Clim 2008, 21:3617-3641. doi:10.1175/2007JCLI1584.1.

89. Sun J-L, Burns SP, Delany AC, Oncley SP, Horst TW, Lenschow DH. Heat balance in the nocturnal boundary layer during CASES-99. J Appl Meteorol 2003, 42:16491666. doi:10.1175/1520-0450(2003)042<1649:HBITNB>2.0.CO;2.

90. McPherson RA, Stensrud DJ, Crawford KC. The impact of Oklahoma's wheat belt on the mesoscale environment. Mon Weather Rev 2004, 132: 405-421. doi:10.1175/1520-0493(2004)132<0405:TIOOWW>2.0.CO;2. 
91. Mahmood R, Hubbard KG, Carlson C. Modification of growing-season surface temperature records in the Northern Great Plains due to land use transformation: verification of modeling results and implications for global climate change. Int J Clim 2004, 24:311-327. doi:10.1002/joc.992.

92. Mahmood R, Foster SA, Keeling T, Hubbard KG, Carlson C, Leeper R. Impacts of irrigation on 20th-century temperatures in the Northern Great Plains. Global Planet Change 2006, 54:1-18. doi:10.1016/j.gloplacha.2005.10.004.

93. Mahmood R, Hubbard KG, Leeper R, Foster SA. Increase in near surface atmospheric moisture content due to land use changes: evidence from the observed dewpoint temperature data. Mon Weather Rev 2008, 136:1554-1561. doi:10.1175/2007MWR2040.1.

94. Sandstrom MA, Lauritsen RG, Changnon D. A central-U.S. summer extreme dewpoint climatology (1949-2000). Phys Geog 2004, 25:191-207.

95. Adegoke JO, Pielke RA, Sr., Carleton AM. Observational and modeling studies of the impacts of agriculture-related land use change on climate in the central U.S. Agric Forest Meteorol 2007, 132: 203-215. doi:10.1002/joc.1996.

96. DeAngelis A, Dominguez F, Fan Y, Robock A, Kustu MD, Robinson D. Evidence of enhanced precipitation due to irrigation over the Great Plains of the United States. J Geophys Res 2010, 115:D15115. doi:10.1029/2010JD013892.

97. Fall S, Niyogi D, Pielke RA, Sr., Gluhovsky A, Kalnay E, Rochon G. Impacts of land use land cover on temperature trends over the continental United States: assessment using the North American regional reanalysis. Int J Climatol 2010, 30:1980-1993. doi:10.1002/joc.1996.

98. Fall S, Diffenbaugh N, Niyogi D, Pielke RA, Sr., Rochon G. Temperature and equivalent temperature over the United States (1979-2005). Int J Climatol 2010, 30:2045-2054. doi:10.1002/joc.2094.

99. Christy JR, Norris WB, Redmond K, Gallo KP. Methodology and results of calculating central California surface temperature trends: evidence of humaninduced climate change? J Clim 2006, 19:548-563. doi:10.1175/JCLI3627.1.

100. Bonfils C, Lobell D. Empirical evidence for a recent slowdown in irrigation induced cooling. Proc Natl Acad Sci 2007, 104:13582-13587. doi:10.1073/ pnas. 0700144104.

101. Lobell DB, Bonfils C. The effect of irrigation on regional temperatures: $\mathrm{a}$ spatial and temporal analysis of trends in California, 1934-2002. J Clim 2008, 21:2064-2071. doi:10.1175/2007JCLI1755.1.

102. Marshall CH, Pielke RA, Sr., Steyaert LT, Willard DA. The impact of anthropogenic land-cover change on the Florida peninsula sea breezes and warm season sensible weather. Mon Weather Rev 2004, 132:28-52. doi:10.1175/1520-0493(2004)132<0028:TIOALC>2.0.CO;2.

103. Raddatz RL. Anthropogenic vegetation transformation and the potential for deep convection on the Canadian prairies. Canad J Soil Sci 1998, 78:657-666. 
104. Raddatz RL. Anthropogenic vegetation transformation and maximum temperatures on the Canadian prairies. Canad Meteorol Oceanograph Soc Bull 1999, 27:167-173.

105. Taylor CM, Gounou A, Guichard F, Harris PP, Ellis RJ, Fleur Couvreux F, De Kauwe M. Frequency of Sahelian storm initiation enhanced over mesoscale soilmoisture patterns. Nature Geosci 2011, 4:430-433. doi:10.1038/ngeo1173.

106. Bonan GB. Effects of land use on the climate of the United States. Clim Change 1997, 37:449-486. doi:10.1023/A:1005305708775.

107. Gallo KP, Owen TW, Easterling DR, Jamason PF. Temperature trends of the U.S. historical climatology network based on satellite designated land use/land cover. J Clim 1999, 12:1344-1348. doi:10.1175/1520-0442(1999)012<1344:TTOTUS>2.0.CO;2.

108. Wichansky PS, Steyaert LT, Walko RL, Weaver CP. Evaluating the effects of historical land cover change on summertime weather and climate in New Jersey: Part I: land cover and surface energy budget changes. J Geophys Res 2008, 113:D10107. doi:10.1029/2007JD008514.

109. Lim Y-K, Cai M, Kalnay E, Zhou L. Observational evidence of sensitivity of surface climate changes to land types and urbanization. Geophys Res Lett 2005, 32:L22712. doi:10.1029/2005GL024267.

110. Segal M, Cramer JH, Pielke RA, Garratt JR, Hildebrand P. Observational evaluation of the snow breeze. Mon Weather Rev 1991, 119:412-424. doi:10.1175/1520-0493(1991)119<0412:0EOTSB>2.0.CO;2.

111. Segal M, Garratt JR, Pielke RA, Hildebrand P, Rogers FA, Cramer J. On the impact of snow cover on daytime pollution dispersion. Atmos Environ 1991, 25B:177192. doi:10.1016/0957-1272(91)90053-H.

112. Avissar R, Liu YQ. Three dimensional numerical study of shallow convective clouds and precipitation induced by land surface forcing. J Geophys Res 1996, 101:7499-7518. doi:10.1029/95JD03031.

113. Niyogi D, Pyle P, Lei M, Arya SP, Kishtawal CM, Shepherd M, Chen F, Wolfe B. Urban modification of thunderstorms: an observational storm climatology and model case study for the Indianapolis urban region. J Appl Meteorol Climatol 2011, 50:1129-1144. doi:10.1175/2010JAMC1836.1.

114. Takata K, Kazuyuki Saitoa K, Yasunari T. Changes in the Asian monsoon climate during 1700-1850 induced by preindustrial cultivation. Proceed Natl Acad Sci 2009, 106:9586-9589. doi:10.1073/pnas.0807346106.

115. Feddema JJ, Oleson KW, Bonan B, Mearns LO, Buja LE, Meehl GA, Washington WM. The importance of land cover change in simulating future climates. Science 2005, 310:1674-1678. doi:10.1126/science.1118160.

116. Gero AF, Pitman AJ, Narisma GT, Jacobson C, Pielke RA, Sr. The impact of land cover change on storms in the Sydney Basin. Global Planet Change 2006, 54:57-78. doi:10.1016/j.gloplacha.2006.05.003. 
117. Graf WL. Dam nation: a geographic census of American dams and their large-scale hydrologic impacts. Water Resour Res 1999, 35:1305-1311. doi:10.1029/1999WR900016.

118. Mesinger F, DiMego G, Kalnay E, Mitchell K, Shafran PC, Ebisuzaki W, Jovic D, Woollen J, Rogers E, Berbery EH, et al. North American regional reanalysis: a long-term, consistent, high-resolution climate dataset for the North American domain, as a major improvement upon the earlier global reanalysis datasets in both resolution and accuracy. Bull Am Meteorol Soc 2006, 87:343-360. doi:10.1175/BAMS-87-3-343.

119. Degu A, Hossain F, Niyogi D, Pielke RA, Sr., Shepherd JM, Voisin N, Chronis T. The influence of large dams on surrounding climate and precipitation patterns. Geophys Res Lett 2011, 38:L04405, doi:10.1029/2010GL046482.

120. Pielke RA, Sr. Influence of the spatial distribution of vegetation and soils on the prediction of cumulus convective rainfall. Rev Geophy 2001, 39:151-177. doi:10.1029/1999RG000072.

121. Huff FA, Changnon S, Jr. Precipitation modification by major urban areas. Bull Am Meteorol Soc 1973, 54: 1220. doi:10.1175/1520-0477(1973)054<1220:PM BMUA>2.0.CO;2.

122. Shepherd JM. Evidence of urban-induced precipitation variability in arid climate regimes. J Arid Environ 2006, 67:607-628. doi:10.1016/j. jaridenv.2006.03.022.

123. Bornstein $\mathrm{R}$, Lin $\mathrm{Q}$. Urban heat islands and summertime convective thunderstorms in Atlanta: three cases studies. Atmos Environ 2000, 34:507516. doi:10.1016/S1352-2310(99)00374-X.

124. Rose LS, Stallins JA, Bentley ML. Concurrent cloud-to-ground lightning and precipitation enhancement in the Atlanta, Georgia (USA) urban region. Earth Interact 2008, 12:1-30. doi:10.1175/2008EI265.1.

125. Mote TL, Lacke MC, Shepherd JM. Radar signatures of the urban effect on precipitation distribution: a case study for Atlanta, Georgia. Geophys Res Lett 2007, 34:L20710. doi:10.1029/2007GL031903.

126. Changnon SA, Shealy RT, Scott RW. Precipitation changes in fall, winter, and spring caused by St. Louis. J Appl Meteorol 1991, 30:126-134. doi:10.1175/1520-0450(1991)030<0126:PCIFWA>2.0.C0;2.

127. Georgescu M, Lobell DB, Field CB. Direct climate effects of perennial bioenergy crops in the United States. Proc Natl Acad Sci 2011, 108:4307-4312. doi:10.1073/pnas.1008779108.

128. Georgescu M, Miguez-Macho G, Steyaert LT, Weaver CP. Climatic effects of 30 years of landscape change over the Greater Phoenix, Arizona, region: 1. Surface energy budget changes. J Geophys Res 2009, 114:D05110. doi:10.1029/2008JD01074. 
129. Georgescu M, Miguez-Macho G, Steyaert LT, Weaver CP. Climatic effects of 30 years of landscape change over the Greater Phoenix, Arizona, region: 2. Dynamical and thermodynamical response. J Geophys Res 2009, 114:D05111. doi:10.1029/2008JD010762.

130. Pitman AJ, Narisma GT, Pielke RA, Sr., Holbrook NJ. The impact of land cover change on the climate of southwest western Australia. J Geophys Res 2004, 109:D18109. doi:10.1029/2003JD004347.

131. Narisma GT, Pitman AJ. The impact of 200 years of land cover change on the Australian near-surface climate. J Hydrometeorol 2003, 4:424-436. doi:10.1175/1525-7541(2003)4<424:TIOYOL>2.0.CO;2.

132. McAlpine CA, Syktus JI, Deo RC, McGowan HA, Lawrence PJ, Watterson IG, Phinn SR. Modeling the impact of historical land cover change on Australia's regional climate. Geophys Res Lett 2007, 34:L22711.

133. Ornstein L, Aleinov I, Rind D. Irrigated afforestation of the Sahara and Australian Outback to end global warming. Clim Change 2009, 97:409-437. doi:10.1007/s10584-009-9626-y.

134. Chang H, Niyogi D, Kumar A, Kishtawal C, Dudhia J, Chen F, Mohanty UC, Shepherd M. Possible relation between land surface feedback and the postlandfall structure of monsoon depressions. Geophys Res Lett 2009, 36:L15826. doi:10.1029/2009GL037781.

135. Kishtawal C, Niyogi D, Balaji R, Rajeevan M, Jaiswal N, Mohanty UC. Inland penetration of monsoon depression depends on pre-storm ground wetnessan observational analysis using Self Organizing Maps. Int J Climatol 2011, submitted for publication.

136. Goswami BN, Venugopal V, Sengupta D, Madhusoodanan MS, Xavier PK. Increasing trend of extreme rain events over India in a warming environment. Science 2006, 314:1442-1445. doi:10.1126/science.1132027.

137. Zhao F. Precipitation Changes Near Three Gorges Dam, China, Master's Thesis. Athens, Georgia: University of Georgia; 2011, 91.

138. Baidya Roy S, Weaver CP, Nolan DS, Avissar R. A preferred scale for landscape forced mesoscale circulations? Journal of Geophysical Research 2003, 108:8854. doi:10.1029/2002JD003097.

139. Pielke RA, Uliasz M. Influence of landscape variability on atmospheric dispersion. J Air Waste Manage 1993, 43:989-994.

140. BaldiM, Dalu GA, Pielke RA, Sr., Meneguzzo F. Analytical evaluation of mesoscale fluxes and pressure field. Environ Fluid Mech 2005, 5:1-2. doi:10.1007/ s10652-005-8089-6,3-33.

141. Avissar R, Pielke RA. A parameterization of heterogeneous land surfaces for atmospheric numerical models and its impact on regional meteorology.

Mon Weather Rev 1989, 117:2113-2136. doi:10.1175/1520-0493 (1989)117<2113:APOHLS>2.0.CO;2. 
142. Hadfield MG, Cotton WR, Pielke RA. Large-eddy simulations of thermally-forced circulations in the convective boundary layer. Part I: a small-scale circulation with zero wind. Boundary-Layer Meteorol 1991, 57:79-114. doi:10.1007/ BF00119714.

143. Hadfield MG, Cotton WR, Pielke RA. Large-eddy simulations of thermally forced circulations in the convective boundary layer. Part II: the effect of changes in wavelength and wind speed. Boundary-Layer Meteorol 1992, 58:307-328. doi:10.1007/BF00120235.

144. Steeneveld G, Wiel B, Holtslag A. Modelling the Arctic stable boundary layer and its coupling to the surface. Boundary-Layer Meteorol 2006, 118: 357-378. doi:10.1007/s10546-005-7771-z.

145. Holtslag B. Preface: GEWEX atmospheric boundary layer study (GABLS) on stable boundary layers. Boundary-Layer Meteorol 2006, 118:243-246.

146. Baumgartner A, Reichel E. The World Water Balance. Amsterdam: Elsevier; 1975, 179. plus maps.

147. de Noblet-Ducoudré N, Boisier J-P, Pitman AJ, Bonan GB, Brovkin V, Cruz F, Delire C, Gayler V, van den Hurk BJJM, Lawrence PJ, et al. Determining robust impacts of land-use induced land-cover changes on surface climate over North America and Eurasia; Results from the first set of LUCID experiments. J Clim 2011, in press.

148. Okin GS, Bullard JE, Reynolds RL, Ballantine J-AC, Schepanski K, Todd MC, Belnap J, Baddock MC, Gill TE, Miller ME. Dust: Small-scale processes with global consequences. Eos Trans AGU 2011, 92:241-241. doi:10.1029/2011E0290001.

149. van der Molen MK, van den Hurk BJJM, Hazeleger WA. Dampened land use change climate response towards the tropics. Clim Dyn 2011, doi:10.1007/ s00382-011-1018-0.

150. Koster RD, Dirmeyer PA, Guo ZC, Bonan G, Chan E, Cox P, Gordon CT, Kanae S, Kowalczyk E, Lawrence D, et al. Regions of strong coupling between soil moisture and precipitation. Science 2004, 305:1138-1140. doi:10.1126/ science.1100217.

151. Seneviratne SI, Lüthi D, Litschi M, Schär C. Land-atmosphere coupling and climate change in Europe. Nature 2006, 443:205-209. doi:10.1038/ nature05095.

152. Findell KR, Knutson TR, Milly PCD. Weak simulated extratropical responses to complete tropical deforestation. J Clim 2006, 19:2835-2850. doi:10.1175/ JCLI3737.1.

153. Findell KL, Shevliakova E, Milly PCD, Stouffer RJ. Modeled impact of anthropogenic land cover change on climate. J Clim 2007, 20:3621-3634. doi:10.1175/JCLI4185.1.

154. Findell KL, Pitman AJ, England MH, Pegion P. Regional and global impacts of land cover change and sea surface temperature anomalies. J Clim 2009, 22:3248-3269. doi:10.1175/2008JCLI2580.1. 
155. Betts RA. Mitigation: a sweetener for biofuels. Nature Clim Change 2011, 1:99101. doi:10.1038/ nclimate1102Year.

156. Betts RA. Implications of land ecosystem-atmosphere interactions for strategies for climate change adaptation and mitigation. Tellus B 2007, 59:602-615. doi:10.1111/j.1600-0889.2007.00284.x.

157. Bonan GB, Pollard D, Thompson SL. Effects of boreal forest vegetation on global climate. Nature 1992, 359:716-717. doi:10.1038/359716a0.

158. Haddeland I, Clark DB, Franssen W, Ludwig F, Vos F, Arnell NW, Bertrand N, Best M, Folwell S, Gerten D, et al. Multi-model estimate of the global water balance: setup and first results. J Hydrometeorol 2011, in press, doi:10.1175/2011JHM1324.1.

159. Hibbard K, Janetos A, van Vuuren DP, Pongratz J, Rose SK, Betts R, Herold M, Feddema JJ. Research priorities in land use and land cover change for the earth system and integrated assessment modelling. Int J Climatol 2010, 30: 21182128. doi:10.1002/joc. 2150.

160. Landman WA, Seth A, Camargo SJ. The effect of regional climate model domain choice on the simulation of tropical cyclone-like vortices in the southwestern Indian Ocean. J Clim 2005, 18:1263-1274. doi:10.1175/JCLI3324.1.

161. Rauscher SA, Seth A, Qian JH, Camargo SJ. Domain choice in an experimental nested modeling prediction system for South America. Theoret Appl Climatol 2006, 86:229-246. doi:10.1007/s00704-006-0206-z.

162. Walsh KJE, Syktus J. Simulations of observed interannual variability of tropical cyclone formation east of Australia. Atmos Sci Lett 2003, 4:28-40. doi:10.1016/ S1530-261X(03)00004-5.

163. Pielke RA, Sr., Wilby R, Niyogi R, Hossain D, Dairuku F, Adegoke K, Kallos J, Seastedt G, Suding T. K Dealing with complexity and extreme events using a bottom-up, resource-based vulnerability perspective. AGU Monograph Complex Extreme Events Geosci 2011, in press. 